\title{
Floating Solar Chimney Technology
}

\author{
Christos D. Papageorgiou \\ National Technical University of Athens
}

Greece

\section{Introduction}

\subsection{Floating Solar Chimney technology description}

The purpose of this chapter is to present the Floating solar chimney (FSC) technology, look for the site www.floatingsolarchimney.gr, in order to explain its principles of operation and to point out its various significant benefits. This technology is the advisable one for candidacy for large scale solar electricity generation especially in desert or semi desert areas of our planet and a major technology for the global warming elimination.

The solar chimney power plants are usually referred to as solar updraft towers (http://en.wikipedia.org/wiki/Solar_updraft_tower) and the related solar chimneys are huge reinforced concrete structures. However due to the high construction cost of the concrete solar chimneys the solar up-draft tower technology is expensive demanding a high initial investment in comparison to its competitive solar technologies. Their solar up-draft towers are huge structures of high initial investment cost that can not be split into small units. That is possible for the relatively also expensive PV solar technology. Also the solar updraft technology is far more expensive compared to the conventional fossil fueled power plants of similar electricity generation. That is why the solar chimney technology has not yet been applied although it is a solar technology of many advantages.

The Floating Solar Chimney (FSC) is a fabric low cost alternative of the concrete solar chimney up-draft towers that can make the Floating Solar Chimney technology cost competitive in comparison not only with the renewable electricity generation technologies but also with the conventional fossil fueled electricity generation technologies. Also the FSC technology is cost effective to be split into small units of several MW each.

The Floating Solar Chimney Power Plant, named by the author as Solar Aero-Electric Power Plant (SAEP) due to its similarity to the Hydro-Electric power plant, is a set of three major components:

- The Solar Collector. It is a large greenhouse open around its periphery with a transparent roof supported a few meters above the ground.

- The Floating Solar Chimney (FSC). It is a tall fabric cylinder placed at the centre of the solar collector through which the warm air of the greenhouse, due to its relative buoyancy to the ambient air, is up-drafting.

- The Turbo-Generators. It is a set of air turbines geared to appropriate electric generators in the path of up-drafting warm air flow that are forced to rotate generating electricity. The gear boxes are adjusting the rotation speed of the air turbines to the generator rotation speed defined by the grid frequency and their pole pairs. 
An indicative figure of a solar chimney Power Plant with a circular solar collector and a Floating Solar Chimney inclined due to external winds is shown in next figure(1).

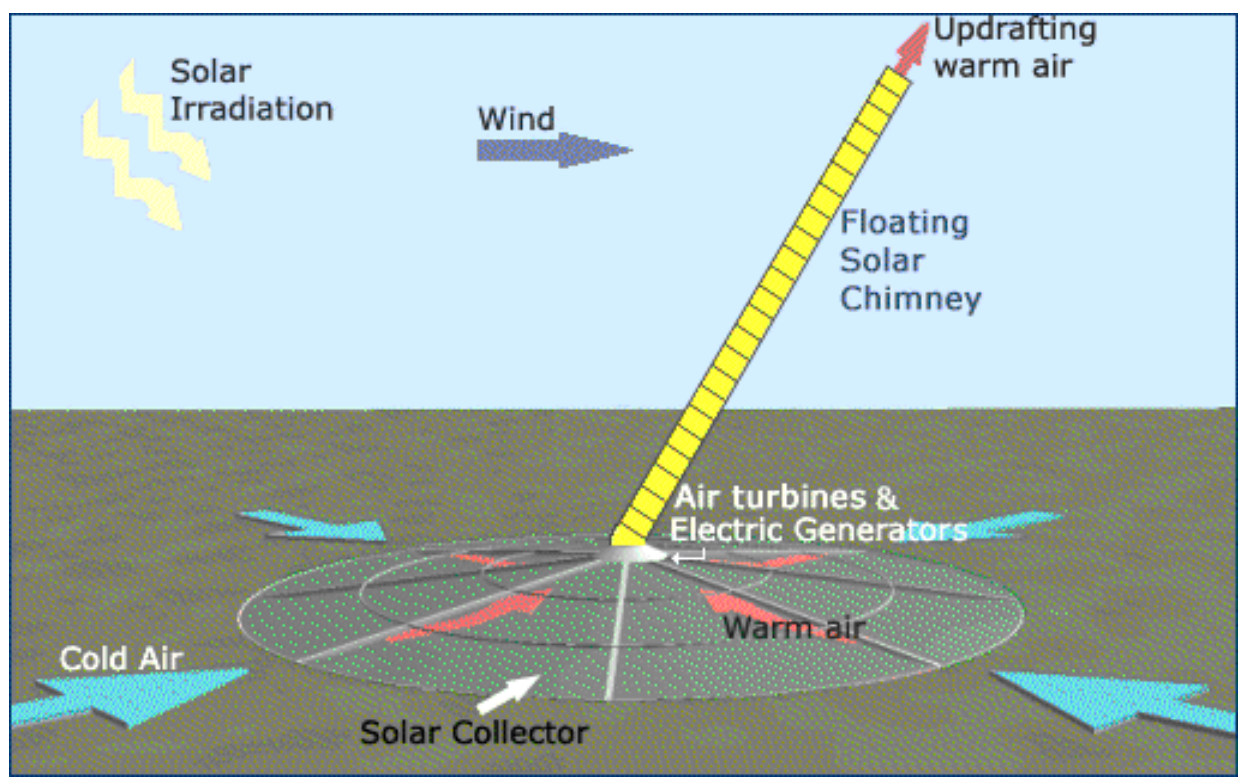

Fig. 1. Floating Solar Chimney Power Plant in operation

Because of its patented construction the FSC is a free standing lighter than air structure that can tilt when external winds appear. Low cost Floating Solar Chimneys up to $1000 \mathrm{~m}$ with internal diameters $25 \mathrm{~m} \div 40 \mathrm{~m}$, can be constructed with an existing polyester fabric, giving to their respective Solar Aero-Electric Power Plants, low investment costs.

By this innovating Floating Solar Chimney Technology of heights of the FSCs up to1000m, up to $1.2 \%$ of the arriving horizontal solar radiation on the solar collector surface, can be converted to electricity

\subsection{Similarity to hydro-electric power plants}

The Floating Solar Chimney power plants, due to their similarity to hydro-electric power plants, are named by the author Solar Aero Electric Power Plants (SAEPs).

Their similarity is due to the following facts:

- The hydro-electric PPs operate due to falling water gravity, while the solar aero-electric PPs operate due to the up-drafting warm air buoyancy.

- The electricity generation units of hydro-electric PPs are water turbines engaged to electric generators while the generation units of solar aero-electric PPs are air turbines engaged to electric generators.

- The energy produced by the hydro-electric PPs is proportional to the falling water height, while the energy produced by the solar aero-electric PPs is proportional to updrafting height of warm air, which is equal to the height of the solar chimneys.

- That is why Prof J. Sclaigh in his book named the solar chimney technology power plants as the hydro-electric power plants of deserts. 


\subsection{Continuous operation}

As it will be shown later the SAEPs operate continuously due to the ground thermal storage. The minimum electric power is generated when the sun is just starting rising, while the maximum electric power is achieved about 2 hours after the sun's maximum irradiation on ground. The power generation profile can become smoother if we increase the solar collector thermal capacity. This can be done by putting on its ground area closed tubes filled with water (as happens already in conventional greenhouses).

\section{History}

The Solar Chimney technology for electricity generation was inspired by several engineering pioneers early in the first decade of the $20^{\text {th }}$ century.

In 1926 Prof Engineer Bernard Dubos proposed to the French Academy of Sciences the construction of a Solar Aero-Electric Power Plant in North Africa with its solar chimney on the slope of a sufficient height mountain. His proposal is shown in the following figure( 2), found in a book of 1954 ( "Engineer's Dream" Willy Ley, Viking Press 1954)

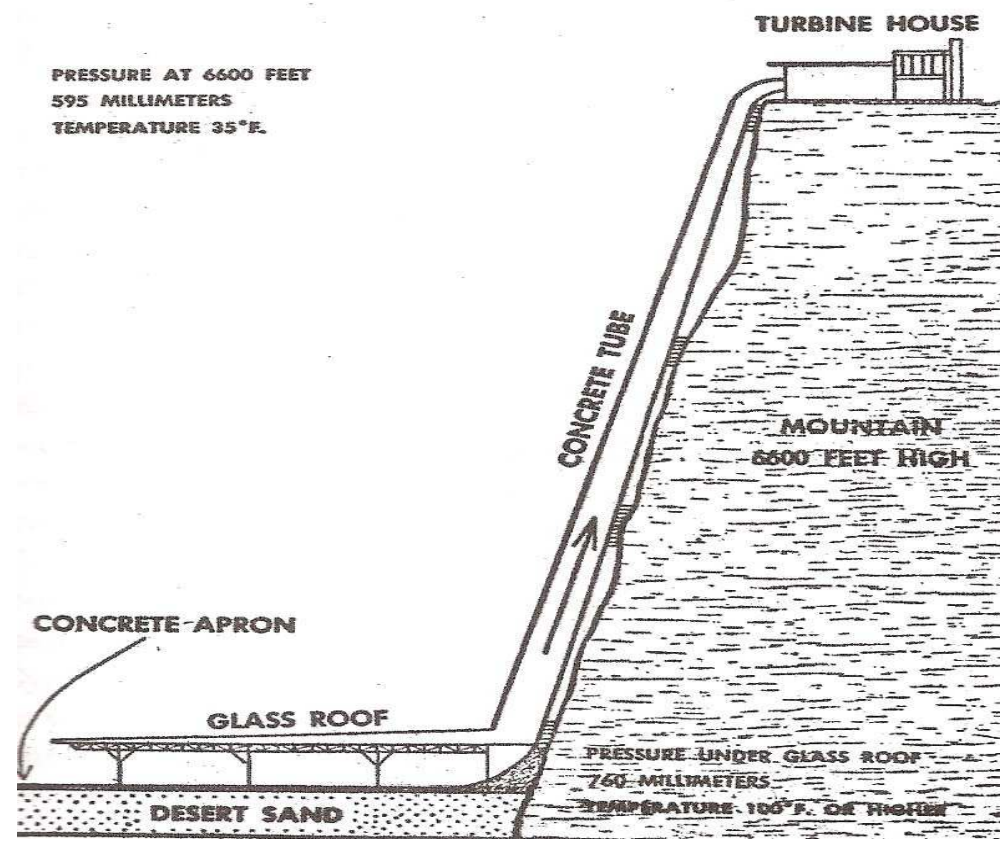

Fig. 2. ( from the book: "Engineer's Dream"By: Willy Ley, Viking Press 1954)

Lately Schaich, Bergerman and Partners, under the direction of Prof. Dr. Ing. Jorg Schlaigh, built an operating model of a SAEPP in 1982 in Manzaranes (Spain), which was funded by the German Government.

This solar chimney power plant, shown in next figure (3) was of rating power $50 \mathrm{KW}$. Its greenhouse had a surface area of $46000 \mathrm{~m}^{2}$ and its solar chimney was made out of steel tubes of $10 \mathrm{~m}$ diameter and had a height of $195 \mathrm{~m}$. 
This demo SAEP was operating successfully for approximately 6 years. During its operation, optimization data were taken.

The collected operational data were in accordance with the theoretical results of the scientific team of Prof Jorg Schlaigh.

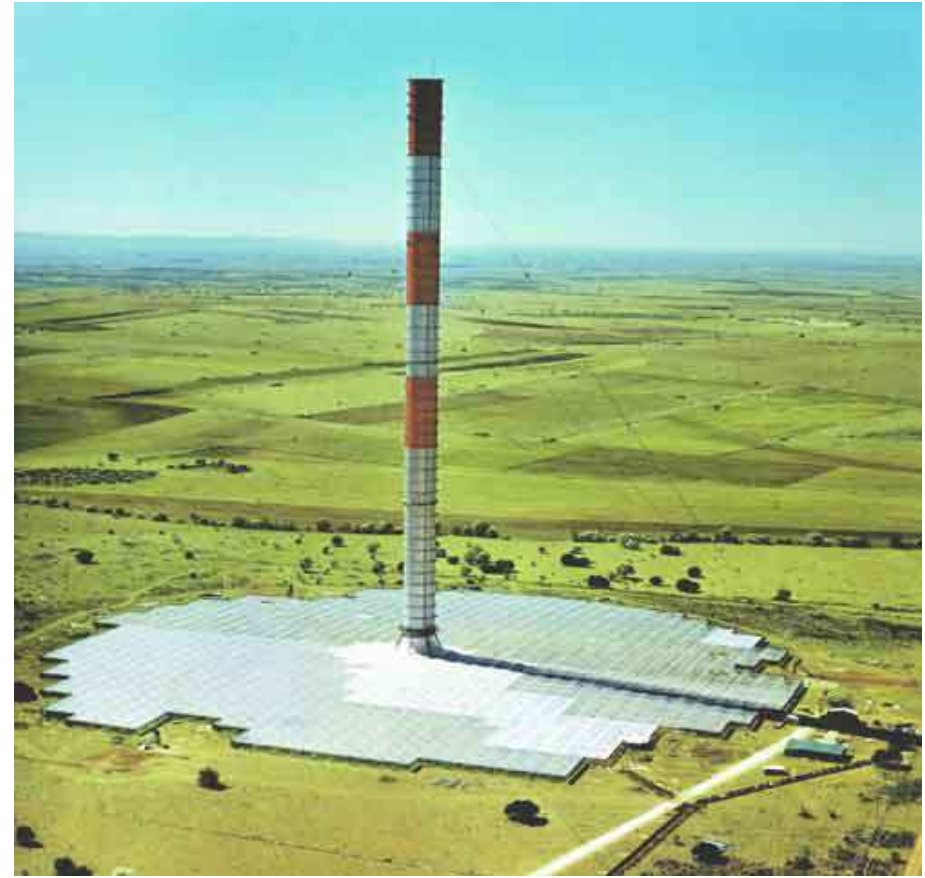

Fig. 3. A view of the Manzanares Solar Chimney Power Plant

Prof. Jorg Schlaigh in 1996 published a book (Schlaigh 1995) presenting the solar chimney technology. He proposed in his book the huge reinforced concrete solar chimneys of heights of $500 \mathrm{~m}-1000 \mathrm{~m}$.

The proposed concrete solar chimneys are huge and very expensive. Therefore the investment cost per produced $\mathrm{KWh}$ on the solar chimney technology with concrete chimneys is in the same cost range with the competitive solar thermal technologies. The generated KWh, by the CSP Parabolic Through for example, it has almost the same direct production cost, but the CSP power plants can be split into small units and developed using reasonable recourses.

However the proposed solar chimney technology had an important benefit in comparison with the major renewable technologies (Wind, SCP, PV).

That is its ability, equipping its solar collectors, with thermal storage facilities of negligible cost, to generate uninterrupted electricity of a controlled smooth profile for $24 \mathrm{~h} /$ day, 365days/year.

The last decade several business plans and a series of scientific research papers have focused on the solar chimney technology, whereby the author with a series of patents and papers has introduced and scientifically supported the floating solar technology (Papageorgiou 2004, 2009). 


\section{Principles of operation of the solar chimney technology and its annual efficiency Information}

\subsection{Short description and principles of operation}

A floating solar chimney power plant (SAEP) is made of three major components:

- A large solar collector, usually circular, which is made of a transparent roof supported a few meters above the ground (the greenhouse). The transparent roof can be made of glass or crystal clear plastic. A second cover made of thin crystal clear plastic is suggested to be hanged just underneath the roof in order to increase its thermal efficiency. The periphery of the solar collector is open in order that the ambient air can move freely into it.

- A tall fabric free standing lighter than air cylinder (the floating solar chimney) placed in the center of the greenhouse which is up drafting the warm air of the greenhouse, due to its buoyancy, to the upper atmospheric layers.

- A set of air turbines geared to appropriate electric generators (the turbo generators), placed with a horizontal axis in a circular path around the base of the FSC or with a vertical axis inside the entrance of the solar chimney. The air turbines are caged and can be just a rotor with several blades or a two stage machine (i.e. with a set of inlet guiding vanes and a rotor of several blades). The gear boxes are adjusting the rotation frequency of the air turbines to the electric generator rotation frequency defined by the grid frequency and the electric generator pole pairs.

The horizontal solar irradiation passing through the transparent roof of the solar collector is heating the ground beneath it. The air beneath the solar collector is becoming warm through a heat transfer process from the ground area to the air. This heat transfer is increased due to the greenhouse effect of the transparent roof.

This warm air becomes lighter than the ambient air. The buoyancy of the warm air is forcing the warm air to escape through the solar chimney. As the warm air is up drafting through the chimney, fresh ambient air is entering from the open periphery of the greenhouse. This fresh air becomes gradually warm, while moving towards the bottom of the solar chimney, and it is also up-drafting.

Thus a large quantity of air mass is continuously circulating from ground to the upper layers of the atmosphere. This circulating air mass flow is offering a part of its thermodynamic energy to the air turbines which rotate and force the geared electric generators also to rotate. Thus the rotational mechanical power of the air turbines is transformed to electrical power. An indicative diagram of the SAEP operation is shown in the next figure(4).

Thus the first two parts of the SAEPs form a huge thermodynamic device up drafting the ground ambient air to the upper atmosphere layers and the third part of the SAEP is the electricity generating unit.

The solar energy arriving on the horizontal surface area $A_{c}$ of the greenhouse of the SAEP is given by $E_{I R}=A_{c} \cdot W_{y}$, where $W y$ is the annual horizontal solar irradiation in $\mathrm{KWh} / \mathrm{m}^{2}$, at the place of installation of the SAEP and is given by the meteorological data nearly everywhere.

The average annual horizontal solar irradiance is given by $G_{a v}=W_{y} / A_{c}$.

The horizontal solar irradiation is offering thermal power $\mathrm{P}_{\mathrm{Th}}=\dot{\mathrm{m}} \cdot \mathrm{c}_{\mathrm{p}} \cdot\left(\mathrm{T}_{03}-\mathrm{T}_{02}\right)$ to the up drafting air mass flow $\dot{\mathrm{m}}$ of the ambient air, $\mathrm{c}_{\mathrm{p}} \approx 1005$ and $\mathrm{T}_{02}$ is equal to the average ambient temperature $\mathrm{T}_{0}$ plus $\sim 0.5{ }^{0} \mathrm{~K}$, in order that it is taken into account the outer air stream increased inlet temperature due to its proximity to the ground on its entrance inside the solar collector. 


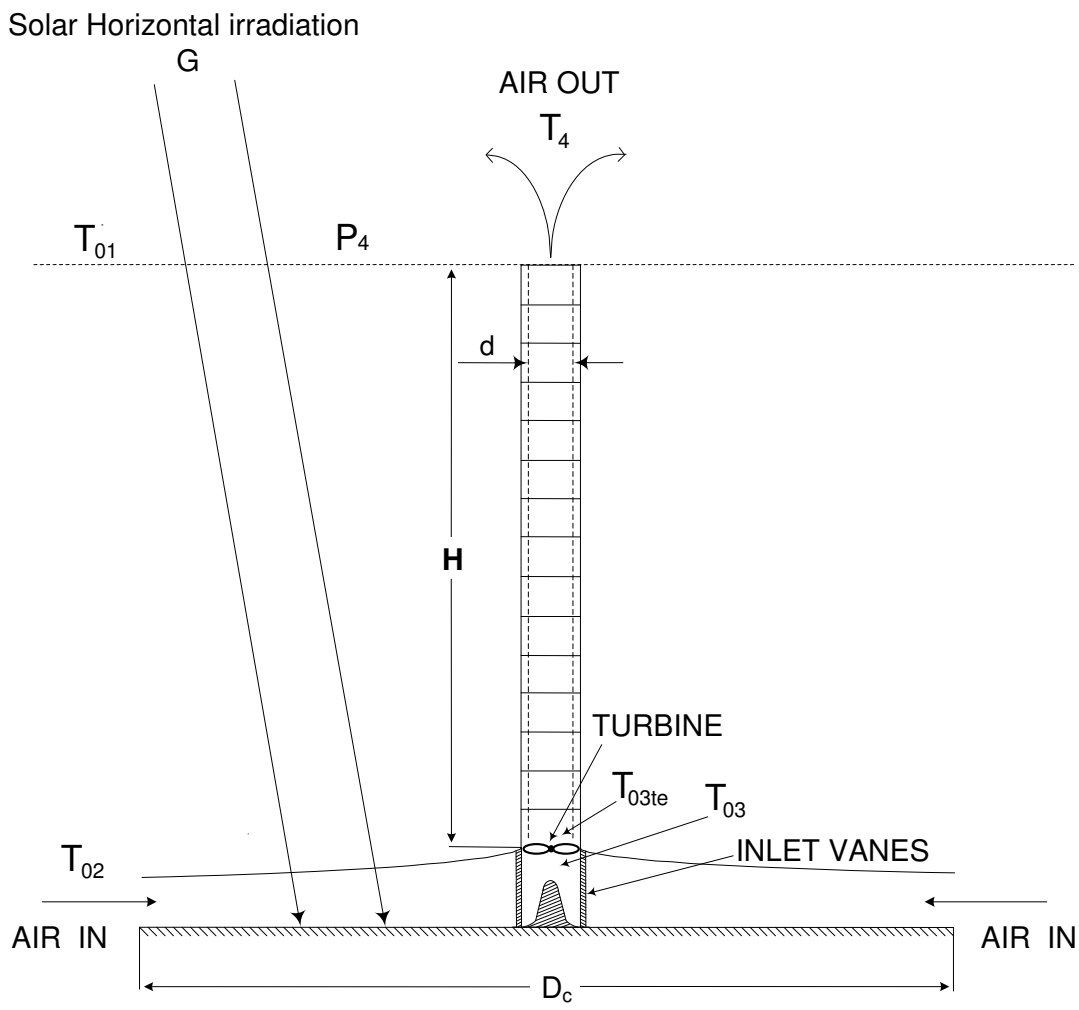

Fig. 4. Schematic diagram of the SAEP in operation

\subsection{Annual average efficiency of SAEPs}

The annual efficiency of the solar collector $\eta_{\mathrm{sc}}$ is defined as the average ratio of the thermal power $\mathrm{P}_{\mathrm{Th}}$ absorbed by the air mass flow to the horizontal solar irradiation arriving on the greenhouse roof $G_{a v} \cdot A_{c}$, where $G_{a v}$ is the average horizontal irradiance and $A_{c}$ the greenhouse surface area.

The annual average double glazing solar collector efficiency $\eta_{\mathrm{sc}}$ is theoretically estimated to $\sim 50 \%$, while the annual efficiency for the single glazing solar collector is estimated to $2 / 3$ of the previous figure i.e. $\sim 33 \%$.

Thus the average exit temperature $\mathrm{T}_{03}$ from the solar collector can be calculated by the equation $\dot{\mathrm{m}} \cdot \mathrm{c}_{\mathrm{p}} \cdot\left(\mathrm{T}_{03}-\mathrm{T}_{02}\right)=\eta_{\mathrm{sc}} \cdot \mathrm{G}_{\mathrm{av}} \cdot \mathrm{A}_{\mathrm{c}}$ where $\mathrm{T}_{02}$ is the average inlet air temperature.

The exit thermal power $\mathrm{P}_{\mathrm{Th}}$ from the solar collector is transformed to electric power $\mathrm{P}$, plus power thermal losses $P_{L}$ (to the air turbines, gear boxes and electric generators), plus warm air kinetic power at the top exit of the solar chimney $P_{\text {KIN }}$ and friction thermal losses inside the solar chimney $P_{\mathrm{FR}}$.

The maximum efficiency of the solar chimney is the Carnot efficiency defined as the ratio of the temperature difference between the incoming and outcoming air temperatures of the updrafting air divided by the ambient air temperature.

This maximum efficiency has been proven (Gannon \& Backstrom 2000) to be equal to: 


$$
\eta_{\mathrm{FSC}, \max }=\mathrm{g} \cdot \mathrm{H} /\left(\mathrm{c}_{\mathrm{p}} \cdot \mathrm{T}_{0}\right)
$$

Due to friction and kinetic losses in the solar chimney the actual solar chimney efficiency $\eta_{\text {FSC }}$ is for a properly designed SAEP approximately $90 \%$ of its maximum Carnot efficiency (close to the optimum point of operation of the SAEP).

The combined efficiency $\eta_{\mathrm{T}}$ of the air turbines, gear boxes and electric generators is within the range of $80 \%$.

The average annual efficiency of the SAEP is the product of the average efficiencies of its three major components i.e. the solar collector, the floating solar chimney and the turbogenerators i.e. $\eta_{\mathrm{av}}=\eta_{\mathrm{sc}} \cdot \eta_{\mathrm{FSC}} \cdot \eta_{\mathrm{T}}$.

Thus the annual average efficiency of a SAEP of proper design, with a double glazing solar collector should be approximately:

$$
\eta_{\mathrm{av}}=(1.2 \cdot \mathrm{H} / 1000) \%
$$

While for the SAEP with a single cover collector it is approximately:

$$
\eta_{\mathrm{av}}=(0.79 \cdot \mathrm{H} / 1000) \% \text {. }
$$

The formulae have been calculated for $\mathrm{g}=9.81, \mathrm{c}_{\mathrm{p}}=1005$ and $\mathrm{T}_{0} \approx 293.2^{\circ} \mathrm{K}\left(20^{\circ} \mathrm{C}\right)$.

This means that if the annual horizontal irradiation arriving on the place of installation of the SAEP is $2000 \mathrm{KWh} / \mathrm{m}^{2}$, the solar collector surface area is $10^{6} \mathrm{~m}^{2}$ (one square $\mathrm{Km}$ ) and the solar chimney height is $750 \mathrm{~m}$ the SAEP can generate approximately 18 million KWh. The same SAEP with a single glazing roof will generate approximately only 12 million KWh.

Following approximate analysis, for a SAEP with a double cover roof of given dimensions ( $\mathrm{Ac}=$ Greenhouse area in $\mathrm{m}^{2}$ and $\mathrm{d}=$ =internal diameter of the Floating Solar Chimney in $\mathrm{m}$ ) to be installed in a place of annual horizontal solar irradiation $\mathrm{Wy}$ in $\mathrm{KWh} / \mathrm{m}^{2}$ the diagram showing the relation between the annual efficiency of the SAEP and its FSC height $\mathrm{H}$ can be calculated.

The following figure (5) shows the annual efficiency as a function of FSC's height for a SAEP of $A c=10^{6} \mathrm{~m}^{2}, \mathrm{~d}=40 \mathrm{~m}$ and $\mathrm{Wy}=1700 \mathrm{KWh} / \mathrm{m}^{2}$ (Cyprus, South Spain).

The calculated efficiency curve is practically independent of the annual horizontal solar irradiation $\mathrm{W}_{\mathrm{y}}$. However it depends on the FSC internal diameter $\mathrm{d}$. The reason is that a smaller diameter will increase the warm air speed at the top exit of the FSC and consequently will increase the kinetic power losses and decrease the average annual efficiency. If we vary the solar collector diameter of the SAEP its FSC internal diameter should vary proportionally in order to keep almost constant the air speed at the top exit of the FSC and consequently the annual efficiency of the SAEP.

Hence we should notice that in order to receive the efficiency diagram as shown in the following figure (5) figure the kinetic and friction losses of the Floating Solar Chimney should be approximately $10 \%$ of the total chimney power. This can be achieved if the internal diameter of the FSC is appropriate in order to keep the average air speed in the range of $7 \div 8 \mathrm{~m} / \mathrm{sec}$, and the FSC internal surface has a low friction loss coefficient.

The following figure (6) shows the variation of the annual efficiency of a SAEP of a FSC $500 \mathrm{~m}$ high, installed in a place of annual horizontal solar irradiation $1700 \mathrm{KWh} / \mathrm{m}^{2}$ as function of the internal diameter of its FSC.

The annual electricity generated by the SAEP, $\mathrm{E}_{\mathrm{y}}$ can be calculated as a product of the annual efficiency and the arriving horizontal solar irradiation on its greenhouse surface $\mathrm{A}_{c} \cdot \mathrm{W}_{\mathrm{y}}$. Thus taking into consideration that the annual efficiency is proportional to the FSC 


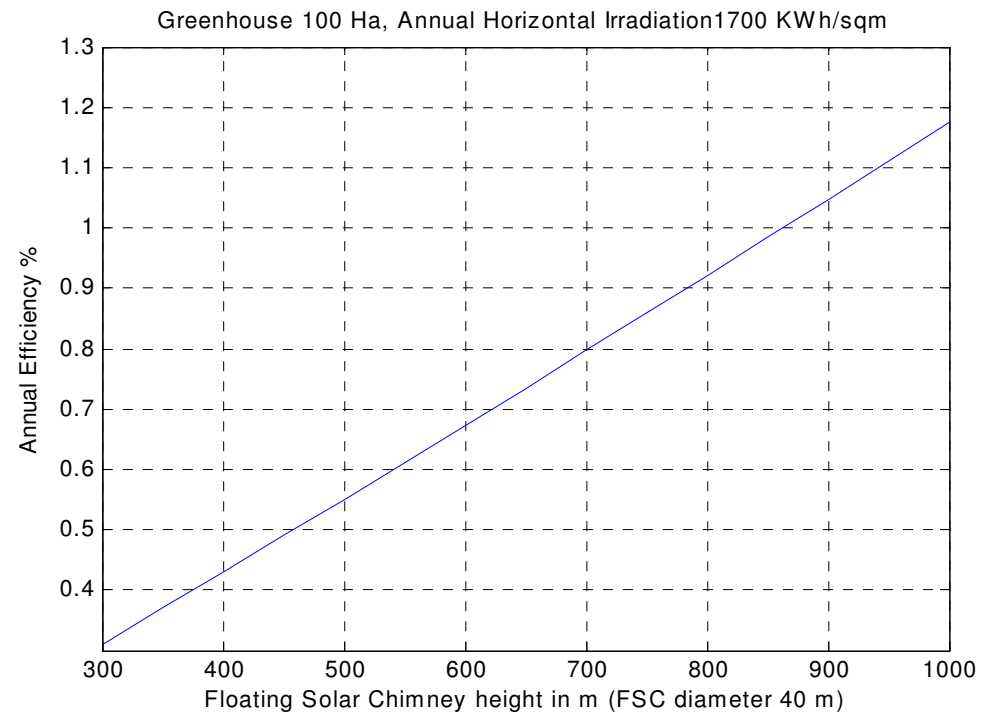

Fig. 5. Annual efficiency of a SAEP as function of its FSC height

height $\mathrm{H}$, the annual generated electricity by the SAEPs is also proportional to the Floating Solar Chimney height $\mathrm{H}$, is as follows:

$$
\mathrm{E}_{\mathrm{y}}=\mathrm{c} \cdot \mathrm{H} \cdot \mathrm{A}_{\mathrm{c}} \cdot \mathrm{W}_{\mathrm{y}}
$$

The constant $\mathrm{c}$ is mainly depending on the FSC's internal diameter $\mathrm{d}$.

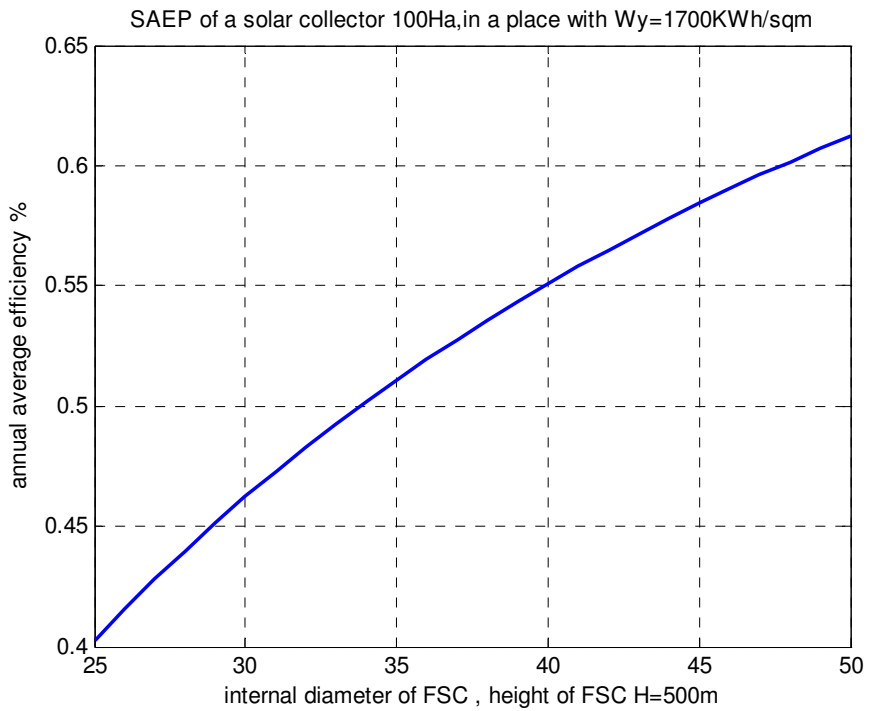

Fig. 6. variation of the annual efficiency of a SAEP with internal FSC diameter 


\section{Theoretical analysis of the Floating Solar Chimney technology}

\subsection{Annual average efficiency of SAEPs}

The ground thermal storage effect and the daily electricity generation profile, have been studied by several authors (Bernades et.al 2003, Pretorius \& Kroger 2006, Pretorious 2007).

The author has used an equivalent approach on the daily power profile study of the floating solar chimney SAEPs using the thermodynamic model see (Backstrom \& Gannon 2000) and Fourier series analysis on the time varying temperatures and varying solar irradiance during the 24 hours daily cycle.

Following the code of the author analysis an evaluation of the sensitivity of the various parameters has been made leading to useful results for the initial engineering dimensioning and design of the SAEPs.

The important results of these studies are that the solar chimney power plant annual power production can be increased by using a second glazing below the outer glazing and its output power production can be affected by the ground roughness and ground solar irradiation absorption coefficients.

The thermodynamic cycle analysis proposed in ref. (Gannon Backstrom 2000) is an excellent way of engineering analysis and thermodynamic presentation of the solar chimney power plant operation.

The thermodynamic cycle of the solar chimney operation power plant using the same symbols of the study of ref (Backstrom \& Gannon 2000) is shown in the following figure.

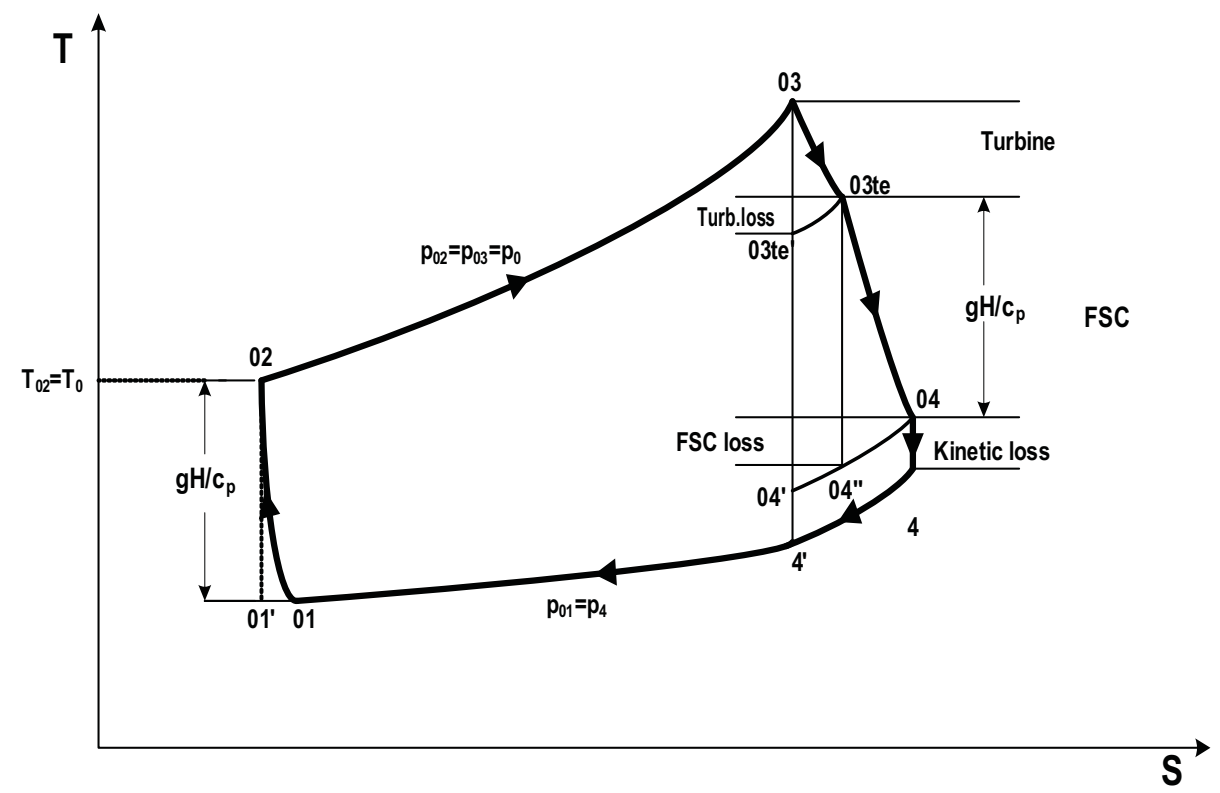

Fig. 7. The thermodynamic diagram of the SAEP

Temperatures, stagnation temperatures (marked with 0) and equivalent isentropic temperatures (marked with ' ) are shown in the indicative diagram on the previous figure. The main thermodynamic cycle temperatures are defined in the following table: 


\begin{tabular}{|l|l|}
\hline $\mathrm{T}_{01}$ & Isendropic temperature of ambient air in height $\mathrm{H}$ (exit of solar chimney) \\
\hline $\mathrm{T}_{02}$ & Ambient temperature in the ground around the solar collector \\
\hline $\mathrm{T}_{03}$ & Inlet temperature in the air turbines \\
\hline $\mathrm{T}_{03 \mathrm{te}}$ & Exit air temperature from the turbo generators \\
\hline $\mathrm{T}_{04}$ & Stagnation temperature at the top of the solar collector \\
\hline $\mathrm{T}_{4}$ & Exit temperature of the air mixed with the ambient air at the top of the exit layers \\
\hline
\end{tabular}

Table 1.Tthermodynamic cycle temperatures

The process $\left\{T_{02}\right.$ to $\left.T_{03}\right\}$ is assumed as approximately isobaric. This assumption is very reasonable taking into consideration that the heat and expansion of moving air is taking place inside the solar collector.

The processes $\left\{\mathrm{T}_{4}\right.$ to $\left.\mathrm{T}_{01}\right\},\left\{\mathrm{T}_{03 \text { te }}\right.$ to $\left.\mathrm{T}^{\prime}{ }_{03 \text { tee }}\right\}$ and $\left\{\mathrm{T}_{04}\right.$ to $\left.\mathrm{T}^{\prime}{ }_{04}\right\}$ are definitely isobaric by nature.

By the analysis on the relations between the temperatures the following relationships can be derived:

$$
\left\{\begin{array}{l}
\mathrm{T}_{04}=\mathrm{T}_{4}+\frac{\mathrm{a} \cdot \mathrm{v}_{e x}^{2}}{2 \cdot c_{\mathrm{p}}}=\mathrm{T}_{4}+\mathrm{C}_{2} \cdot \mathrm{T}_{4}^{2}, \mathrm{~T}_{03 \mathrm{te}}=\mathrm{T}_{04}+\frac{\mathrm{g} \cdot \mathrm{H}}{c_{\mathrm{p}}} \\
\mathrm{T}_{03 \mathrm{te}}^{\prime}=\mathrm{T}_{03}-\frac{\mathrm{T}_{03}-\mathrm{T}_{03 \mathrm{te}}}{\mathrm{n}_{\mathrm{T}}}, \mathrm{T}_{04}^{\prime \prime}=\mathrm{T}_{04}-\mathrm{k} \cdot \frac{\mathrm{a} \cdot \mathrm{v}_{e x}^{2}}{2 \cdot c_{\mathrm{p}}} \\
\mathrm{T}_{04}^{\prime}=\frac{\mathrm{T}_{4}^{\prime} \cdot \mathrm{T}_{04}}{\mathrm{~T}_{4}} \text { and } \mathrm{T}_{04}^{\prime \prime}=\mathrm{T}_{03} \cdot \frac{\mathrm{T}_{04}^{\prime}}{\mathrm{T}_{03 \mathrm{te}}^{\prime}}
\end{array}\right.
$$

Whereby the parameters participating in the relations are defined as follows:

$\mathrm{H}=$ solar chimney height

$\mathrm{d}=$ internal solar chimney diameter

$\mathrm{A}_{\mathrm{ch}}=\Pi \cdot \mathrm{d}^{2} / 4$, is the solar chimney internal cut area

$\dot{\mathrm{m}}=$ moving mass flow

$a=$ kinetic energy correction coefficient, of a usual value of 1.058 calculated in (White 1999).

$\mathrm{k}=$ friction loss coefficient inside the solar chimney

$k=k_{\text {in }}+4 \cdot C_{d} \cdot H / d$ where, for the operation range of Reynolds numbers inside the solar chimney, the drag friction factor $C_{d}$ is approximately equal to 0.003 , see (White 1999) and for no available data $\mathrm{k}_{\mathrm{in}}$ it is estimated to 0.15 .

$\eta_{\mathrm{T}}=$ turbo generators overall efficiency, if not available data estimated to 0.8 .

$\mathrm{T}_{0}=$ ambient air temperature

$\mathrm{T}_{02}=\mathrm{T}_{0}+0.5$

$\mathrm{p}_{0}=$ ambient atmospheric pressure on ground level at the place of installation of the SAEP, if not available data it is assumed as equal to $101300 \mathrm{~Pa}$.

$\mathrm{p}_{4}=$ ambient atmospheric pressure on top exit at height $\mathrm{H}$, estimated by the formula:

$$
p_{4}=p_{0} \cdot\left(1-\frac{\mathrm{g} \cdot \mathrm{H}}{c_{\mathrm{p}} \cdot T_{0}}\right)^{3.5}
$$

$\mathrm{g}=$ gravity constant 9.81 
$\mathrm{C}_{\mathrm{p}}=$ specific heat of air approximately equal to 1005

$\mathrm{R}=$ air constant approximately equal to 287

$\mathrm{v}_{\mathrm{ex}}=$ average air speed at the top exit of the solar chimney $\mathrm{v}_{\mathrm{ex}}=\frac{\mathrm{R} \cdot \mathrm{T}_{4} \cdot \dot{\mathrm{m}}}{\mathrm{P}_{4} \cdot \mathrm{A}_{\mathrm{ch}}}$

and: $\mathrm{T}_{4}^{\prime}=\mathrm{T}_{03} \cdot \frac{\mathrm{T}_{0}-\mathrm{C}_{1}}{\mathrm{~T}_{0}}, \mathrm{C}_{1}=\frac{\mathrm{g} \cdot \mathrm{H}}{c_{\mathrm{p}}}, \mathrm{C}_{2}=\frac{a}{2 \cdot c_{\mathrm{p}}} \cdot\left(\frac{\mathrm{R} \cdot \dot{\mathrm{m}}}{\mathrm{A}_{\mathrm{ch}} \cdot \mathrm{p}_{4}}\right)^{2}, \mathrm{C}_{3}=\mathrm{T}_{03} \cdot\left(\mathrm{\eta}_{\mathrm{T}}-1\right)+\frac{\mathrm{g} \cdot \mathrm{H}}{\mathrm{c}_{\mathrm{p}}}$

The system of the previous equations can been simplified (see Papageorgiou, 2004),leading to a forth order polynomial equation for $\mathrm{T}_{4}$ given by:

$$
w_{1} \cdot \mathrm{T}_{4}^{4}+w_{2} \cdot \mathrm{T}_{4}^{3}+w_{3} \cdot \mathrm{T}_{4}^{2}+w_{4} \cdot \mathrm{T}_{4}+w_{5}=0
$$

Where the coefficients $\mathrm{w}_{1}, \mathrm{w}_{2}, \mathrm{w}_{3}, \mathrm{w}_{4}$ and $\mathrm{w}_{5}$ are given by the relations:

$$
\begin{aligned}
& \mathrm{w}_{1}=\mathrm{C}_{2}^{2} \cdot(1-\mathrm{k}), w_{2}=\mathrm{C}_{2} \cdot\left(2-\mathrm{k}-\mathrm{\eta}_{\mathrm{T}} \cdot \mathrm{C}_{2} \cdot \mathrm{T}_{4}^{\prime}\right), w_{3}=(1-\mathrm{k}) \cdot \mathrm{C}_{2} \cdot \mathrm{C}_{3}+1-2 \cdot \eta_{\mathrm{T}} \cdot \mathrm{C}_{2} \cdot \mathrm{T}_{4}^{\prime} \\
& w_{4}=\mathrm{C}_{3}-\mathrm{\eta}_{\mathrm{T}} \cdot \mathrm{T}_{4}^{\prime} \cdot\left(1-\mathrm{C}_{1} \cdot \mathrm{C}_{2}\right), \mathrm{w}_{5}=-\mathrm{\eta}_{\mathrm{T}} \cdot \mathrm{T}_{4}^{\prime} \cdot \mathrm{C}_{1}
\end{aligned}
$$

The proper root of the previous polynomial equation is the temperature $\mathrm{T}_{4}$.

It is easy using the previous relations to calculate $\mathrm{T}_{03 \text { te }}$ by the formula:

$$
\mathrm{T}_{03 \mathrm{te}}=\mathrm{T}_{4}+\mathrm{C}_{2} \cdot \mathrm{T}_{4}^{2}+\frac{\mathrm{g} \cdot \mathrm{H}}{c_{\mathrm{p}}}
$$

Thus the overall electrical power of the generators is given by the relation:

$$
P=\dot{\mathrm{m}} \cdot c_{p} \cdot\left(\mathrm{T}_{03}-\mathrm{T}_{03 \mathrm{te}}\right)=\dot{\mathrm{m}} \cdot c_{p} \cdot\left(\mathrm{T}_{03}-\mathrm{T}_{4}-\mathrm{C}_{2} \cdot \mathrm{T}_{4}^{2}-\frac{\mathrm{g} \cdot \mathrm{H}}{c_{\mathrm{p}}}\right)
$$

As a final result we can say that the air mass flow $\dot{m}$ and the exit temperature $\mathrm{T}_{03}$ of the moving air mass through solar collector can define, through the previous analytical procedure, based on the thermodynamic cycle analysis, the electrical power output $\mathrm{P}$ of the SAEP.

The proposed thermodynamic analysis, though it looks more complicated than the analysis based on the buoyancy of warm air inside the chimney and the relevant pressure drop to the air turbine used by Bernades M.A. dos S., Vob A., Weinrebe G. and Pretorius J.P., Kroger D.G., it is an equivalent thermodynamic analysis that takes into consideration all necessary and non negligible effects and parameters of the process in the SAEP.

An approximate procedure for $\mathrm{T}_{03}$ calculation is given by Shlaigh in his relative book.

The approximate average equation relating the average exit solar collector air temperature $\mathrm{T}_{03}$ to its input air temperature $\mathrm{T}_{02}$ near the point of optimal operation of the SAEP can be written as follows:

$$
\text { ta } \mathrm{G}_{\mathrm{av}} \cdot \mathrm{A}_{\mathrm{c}}=\dot{m} \cdot \mathrm{C}_{\mathrm{p}} \cdot\left(\mathrm{T}_{03}-\mathrm{T}_{02}\right)+\beta \cdot \mathrm{A}_{\mathrm{c}} \cdot\left(\mathrm{T}_{03}-\mathrm{T}_{02}\right)
$$

where:

- $\quad \beta$ is the approximate thermal power losses coefficient of the Solar Collector (to the ambient and ground) per $\mathrm{m}^{2}$ of its surface area and ${ }^{\circ} \mathrm{C}$ of the temperature difference $\left(\mathrm{T}_{03}-\mathrm{T}_{02}\right)$. An average value of $\beta$ for double glazing solar collectors is $\sim 3.8 \div 4 \mathrm{~W} / \mathrm{m}^{2} /{ }^{\circ} \mathrm{C}$. 
- Gav is the annual average horizontal irradiance on the surface of the solar collector.

- The annual average solar horizontal irradiance $G_{a v}$ is given by the formula: $\mathrm{Wy} / 8760$ hours, where $\mathrm{W}_{\mathrm{y}}$ is the annual horizontal irradiation of the place of installation of the SAEPP, (in $\mathrm{KWh} / \mathrm{m}^{2}$ )

- ta is the average value of the product: \{roof transmission coefficient for solar irradiation $\mathrm{X}$ soil absorption coefficient for solar irradiation\}.An average value of the coefficient ta for a double glazing roof is $\sim 0.70$.

- $\quad$ and Ac is the Solar Collector's surface area.

Using in the equation an approximation for the function $\mathrm{T}_{03}(\dot{m})$, it gives as:

$$
\mathrm{T}_{03}(\dot{m})=\left[\text { ta } \mathrm{G} /\left(\beta+\dot{m} \cdot \mathrm{C}_{\mathrm{p}} / \mathrm{A}_{\mathrm{c}}\right)\right]-\mathrm{T}_{02}
$$

Where $\mathrm{T}_{02}$ is, approximately, equal to the ambient temperature $\left(\mathrm{T}_{0}\right.$ in $\left.{ }^{0} \mathrm{~K}\right)$, plus 0.5 degrees of Celsius. The increase is due mainly to ground thermal storage around the Solar Collector. The inlet ambient air temperature as passing above it is increasing entering to the solar collector.

The proper value of $\beta$, giving the average solar collector thermal losses, has been calculated by the heat transfer analysis of the solar collector. An introduction on this analysis is given on the next paragraph. The heat transfer analysis uses time Fourier series in order to take into account the ground thermal storage phenomena during a daily cycle of operation.

The instantaneous efficiency of the SAEP is given by the formula:

$$
\eta=P /\left(A_{C} \cdot G\right)
$$

where $A_{C} \cdot G$ is the solar irradiation power arriving on the horizontal solar collector surface area $A_{c}$ and $P$ is the maximum generated electric power. This efficiency is for a given value of horizontal solar irradiance G. However we can prove that for an almost constant mass flow near the point of maximum power output, the maximum electric power $\mathrm{P}$ and the horizontal irradiance $\mathrm{G}$ are almost proportional, thus the previous formula is giving also the annual efficiency of the SAEP defined as the annual generated electricity in KWh divided by the annual horizontal irradiation arriving on top of the roof of the greenhouse of the SAEP i.e

$$
\eta=P_{a v} /\left(A_{C} \cdot G_{a v}\right)=E_{y}(K W h) / W_{Y}
$$

As an example let us consider that a SAEP has the following dimensions and constants: $\mathrm{A}_{\mathrm{c}}=10^{6} \mathrm{~m}^{2}(\mathrm{DD}=1000 \mathrm{~m}), \mathrm{H}=800 \mathrm{~m}, \mathrm{~d}=40 \mathrm{~m}, \mathrm{k}=0.49, \mathrm{a}=1.1058, \eta_{\mathrm{T}}=0.8$, the average ambient temperature is $T_{o}=296.2 \circ \mathrm{K}$ and the ambient pressure is $P_{o}=101300 \mathrm{~Pa}$. Let us assume that the horizontal solar irradiance $G$ is varying between $100 \mathrm{~W} / \mathrm{m}^{2}$ to $500 \mathrm{~W} / \mathrm{m}^{2}$ $\left(\mathrm{G}_{\mathrm{av}} \approx 240 \mathrm{~W} / \mathrm{m}^{2}\right)$. In following figure the effect of the $\mathrm{G}$ on the power output as function of mass flow of this SAEP is shown.

If the maximum (daily average during summer operation) $G_{a v}$ is $500 \mathrm{~W} / \mathrm{m}^{2}$ the maximum power output of this SAEP, achieved for $\dot{m}_{M}=\sim 10000 \mathrm{Kg} / \mathrm{sec}$ is $5 \mathrm{MW}$. Thus its efficiency is approximately $1 \%$. Let us assume that the rated power output $P_{R}$ of a SAEP is the maximum power output for the maximum average solar irradiance. As we can observe on the above figure, the maximum power output point of operation $\left(\dot{m}_{M}\right)$ is approximately the same for any horizontal solar irradiance $\mathrm{G}$. 


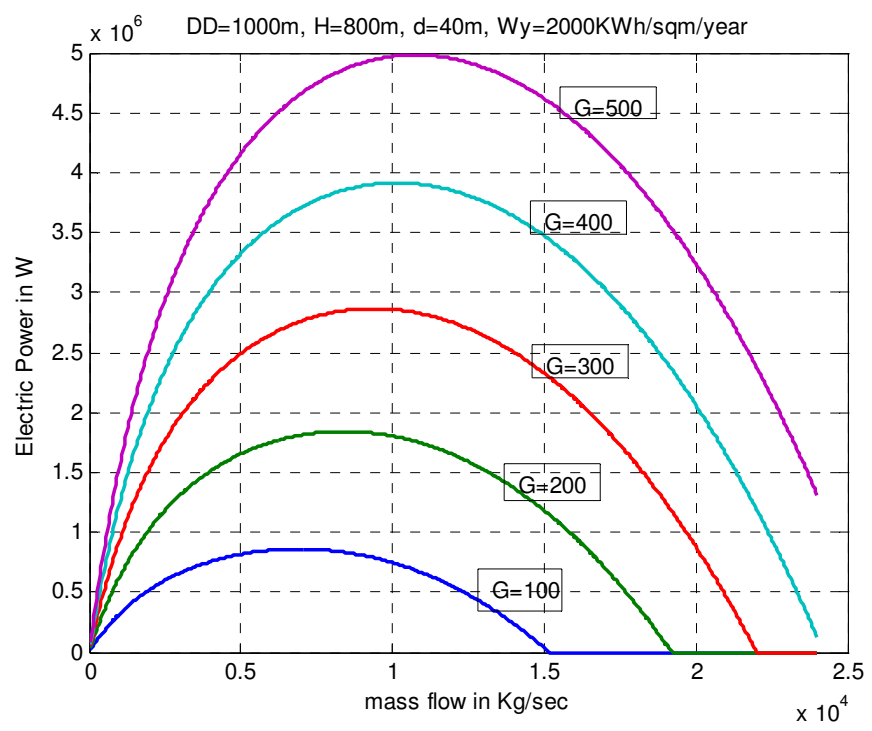

Fig. 9. Electrical Power as function of mass flow for various values of $G$

Thus if we can control the operation of the SAEP to operate with the proper constant mass flow, close to $\dot{m}_{M}$, we should achieve almost the possible maximum electric power output by the SAEP for any horizontal solar irradiance. This is referred to as an optimal operation of the SAEP.

As we see later this can be achieved by using induction generators and gear boxes of proper transmission rate.

As a rule of thumb we can state that $\dot{m}_{M}$ for optimal operation of the SAEP can be calculated approximately by the formula $\dot{m}_{M}=\rho \cdot \mathrm{v} \cdot\left(\Pi \cdot \mathrm{d}^{2} / 4\right)$, where air speed is $\mathrm{v}$ it is estimated to $7-8 \mathrm{~m} / \mathrm{sec}$, the air density is given by $\rho=\mathrm{p}_{0} /(287 \cdot 307.15)$ and $d$ is the internal solar chimney diameter.

A more accurate calculation can be done if we work out on the mass flow for maximum electric power output per annual average horizontal solar irradiance $G_{a v \text {,annual }}=W y / 8760$. This can be done using the thermodynamic cycle analysis for variable mass flow $\dot{m}$ and $G_{a v}$. The calculated efficiency for the annual average horizontal solar irradiance $\mathrm{G}_{\mathrm{av}}=2100000 / 8760 \approx 240 \mathrm{~W} / \mathrm{m}^{2}$, of the previously defined SAEP, is $0.94 \%$ (i.e. $6 \%$ lower than the calculated efficiency of $1 \%$ for the maximum summer average horizontal solar irradiance of $\left.500 \mathrm{~W} / \mathrm{m}^{2}\right)$.

\subsection{Maximum exit warm air speed without air turbines}

Using the thermodynamic cycle diagram, the maximum top exit warm air speed of the solar collector plus the FSC alone (i.e. without the air turbines) can be calculated.

In the previous set of equations we should assume that $\mathrm{n}_{\mathrm{T}}=0$. Thus: 
$\mathrm{T}_{03}=\mathrm{T}_{03 \text { te }}$ and $\mathrm{T}_{04}^{\prime}=\mathrm{T}_{04}^{\prime \prime}$. If we consider that the kinetic losses are approximately equal to $\mathrm{T}_{04}^{\prime}-\mathrm{T}_{4}^{\prime} \approx \frac{a \cdot v^{2}}{2 \cdot c_{p}}$, the friction losses are equal to $\mathrm{T}_{04}^{\prime \prime}-\mathrm{T}_{04}^{\prime}=k \cdot \frac{a \cdot v^{2}}{2 \cdot c_{p}}$ and taking into consideration that the equations $\mathrm{T}_{4}^{\prime}=\mathrm{T}_{03} \cdot \frac{\mathrm{T}_{0}-\mathrm{C}_{1}}{\mathrm{~T}_{0}}, \mathrm{C}_{1}=\frac{\mathrm{g} \cdot \mathrm{H}}{c_{\mathrm{p}}}$ the following relation is derived:

$$
2 \cdot \mathrm{g} \cdot \mathrm{H} \cdot \frac{\Delta \mathrm{T}}{\mathrm{T}_{0}}=(k+1) \cdot a \cdot v^{2}
$$

Where $\Delta \mathrm{T}=\mathrm{T}_{03}-\mathrm{T}_{0}$ (we can approximately consider that $\mathrm{T}_{0} \approx \mathrm{T}_{02}$ ).

Thus the maximum exit top air speed in a free passage solar chimney (without air turbines) is given by the formula:

$$
v=\sqrt{2 \cdot \mathrm{g} \cdot \mathrm{H} \cdot \frac{\Delta \mathrm{T}}{\mathrm{T}_{0}} /[(k+1) \cdot a]} .
$$

For example the exit top speed of the up-drafting air inside the FSC of $\mathrm{H}=800 \mathrm{~m}$ height, with ordinary values for coefficients $\mathrm{a}=1.1058$ and $\mathrm{k}=0.49$ and ambient air temperature $\mathrm{T}_{0}=296.2$ ${ }^{0} \mathrm{~K}\left(23^{\circ} \mathrm{C}\right)$ as function of $\Delta \mathrm{T}$ is given in the next figure:

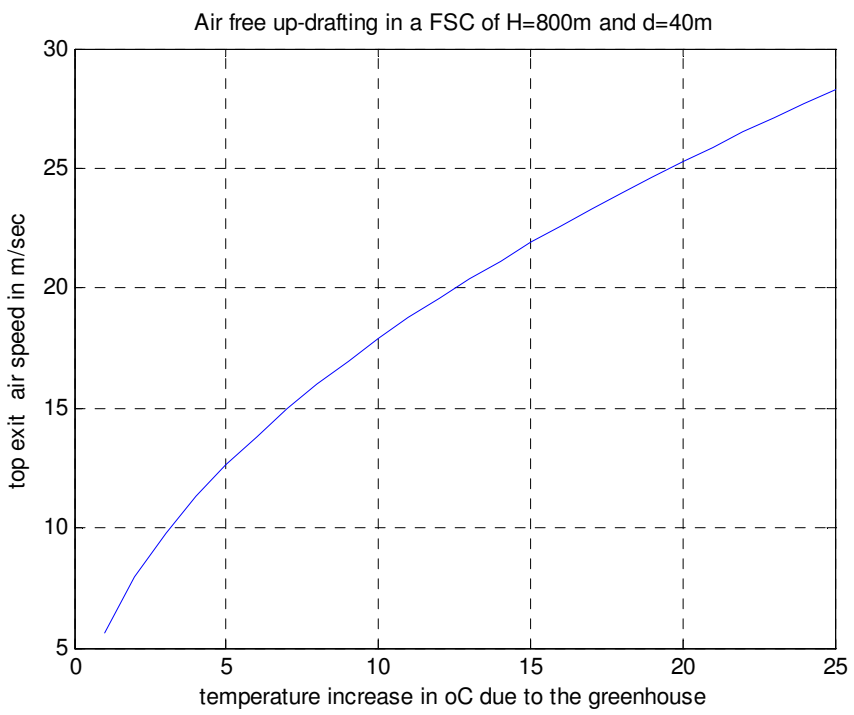

Fig. 10. Free air speed as a function of temperature increase

The temperature increase $\Delta T$ as a function of the greenhouse surface area $A_{c}$ is given by the approximate formula $\Delta \mathrm{T} \approx$ ta $G /\left(\beta+\dot{m} c_{\mathrm{p}} / \mathrm{A}_{\mathrm{c}}\right)$ where ta $\approx 0.7, \quad \beta \approx 4, \mathrm{c}_{\mathrm{p}}=1005$, and $\dot{m}_{M}=\rho \cdot \mathrm{v} \cdot\left(\Pi \cdot \mathrm{d}^{2} / 4\right)$ where $\rho \approx 1.17 \mathrm{Kg} / \mathrm{m}^{3}$, and $\mathrm{d}=40 \mathrm{~m}$. Thus The approximate double glazing solar collector area, generating the free up-drafting air speed $\mathrm{v}$ can be defined by $\Delta \mathrm{T}, \mathrm{v}$ and $\mathrm{G}$ by the equation $\mathrm{A}_{\mathrm{c}} \approx \dot{m} c_{\mathrm{p}} /[($ ta $\mathrm{G}) / \Delta \mathrm{T}-\beta]$. 
The approximate solar collector area $\mathrm{A}_{\mathrm{c}}$ as a function of the temperature increase $\Delta \mathrm{T}$ for various values of equivalent horizontal solar irradiance $G=250,300,350,400$ and $450 \mathrm{~W} / \mathrm{m}^{2}$, is shown in the following figure.

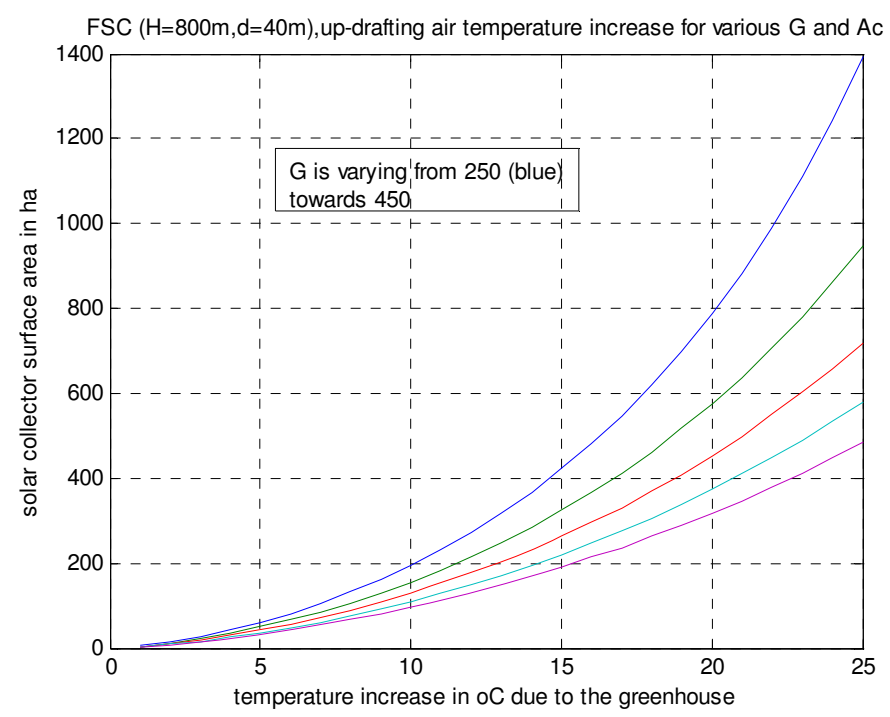

Fig. 11. The solar collector area as a function of its generating temperature increase

Example: for a solar collector of surface area $\mathrm{A}_{\mathrm{c}}=400 \mathrm{Ha}$ (i.e. $400000 \mathrm{~m}^{2}$ ), with a diameter $D_{c} \approx 715 \mathrm{~m}$, for an equivalent horizontal solar irradiation $G$ of $250 \mathrm{~W} / \mathrm{m}^{2}$, the created temperature difference $\Delta \mathrm{T}$ is $\sim 14.5^{\circ} \mathrm{C}$ and the free up-drafting air speed $\mathrm{v}$ inside the FSC of $\mathrm{H}=800 \mathrm{~m}$ height and $\mathrm{d}=40 \mathrm{~m}$ internal diameter will be $\sim 21 \mathrm{~m} / \mathrm{sec}$, while for $\mathrm{G}=450 \mathrm{~W} / \mathrm{m}^{2}, \Delta \mathrm{T}$ is $\sim 22.5^{\circ} \mathrm{C}$ and $\mathrm{v}$ is $\sim 27 \mathrm{~m} / \mathrm{sec}$.

For one dimensional analysis $a \approx 1$ and if the friction losses are negligible, i.e. $k \approx 0$, we have:

$$
v \approx \sqrt{2 \cdot \mathrm{g} \cdot \mathrm{H} \cdot \frac{\Delta \mathrm{T}}{\mathrm{T}_{0}}}
$$

Therefore free up-drafting warm air top speed formula, in an adiabatic and free friction FSC, due to its buoyancy, is similar to free falling water speed due to gravity given by:

$$
v_{\text {water }} \approx \sqrt{2 \cdot \mathrm{g} \cdot \mathrm{H}}
$$

\subsection{The thermal heat transfer model of the SAEP}

In order to use the previous thermodynamic cycle analysis of the SAEP we should calculate the warm air temperature $\mathrm{T}_{03}$ at the entrance of the air turbine or at the exit of the solar collector. The calculation of this average temperature can be done by using the previously proposed approximate analysis. However the temperature $\mathrm{T}_{03}$ is varying during the 24 hours daily cycle.

In order for the daily variation to be calculated and consequently the electric power daily variation using the previously proposed thermodynamic cycle analysis, we should make a 
heat transfer model and use it for the calculation of the exit temperature as function mainly of daily horizontal irradiance profile and ambient temperature daily profile.

The SAEP heat transfer model with a circular collector is shown in the indicative diagram of the previous figure.

The circular solar collector of this SAEP is divided into a series of M circular sectors of equal width $\Delta \mathrm{r}$ as shown in the next figure.

In this figure the cut of a circular sector of the solar collector of the SAEP is shown with the heat transfer coefficients of the process (radiation and convection) and the temperatures of ground $\left(\mathrm{T}_{\mathrm{s}}\right)$, moving air $(\mathrm{T})$, inner curtain $\left(\mathrm{T}_{\mathrm{c}}\right)$, outer glazing $\left(\mathrm{T}_{\mathrm{w}}\right)$, ambient air $\left(\mathrm{T}_{0}\right)$ and sky $\left(\mathrm{T}_{\mathrm{sk}}\right)$. The ground absorbs a part of the transmitted irradiation power due to the horizontal solar irradiance $G$ (ta $G)$.

The wind is moving with a speed $\mathrm{v}_{\mathrm{w}}$ and on the ground it is a thin sheet of water inside a dark plastic film. The ground is characterized by its density $\rho_{g r}$, its specific heat capacity $c_{g r}$ and its thermal conductivity $\mathrm{kgr}_{\mathrm{gr}}$.

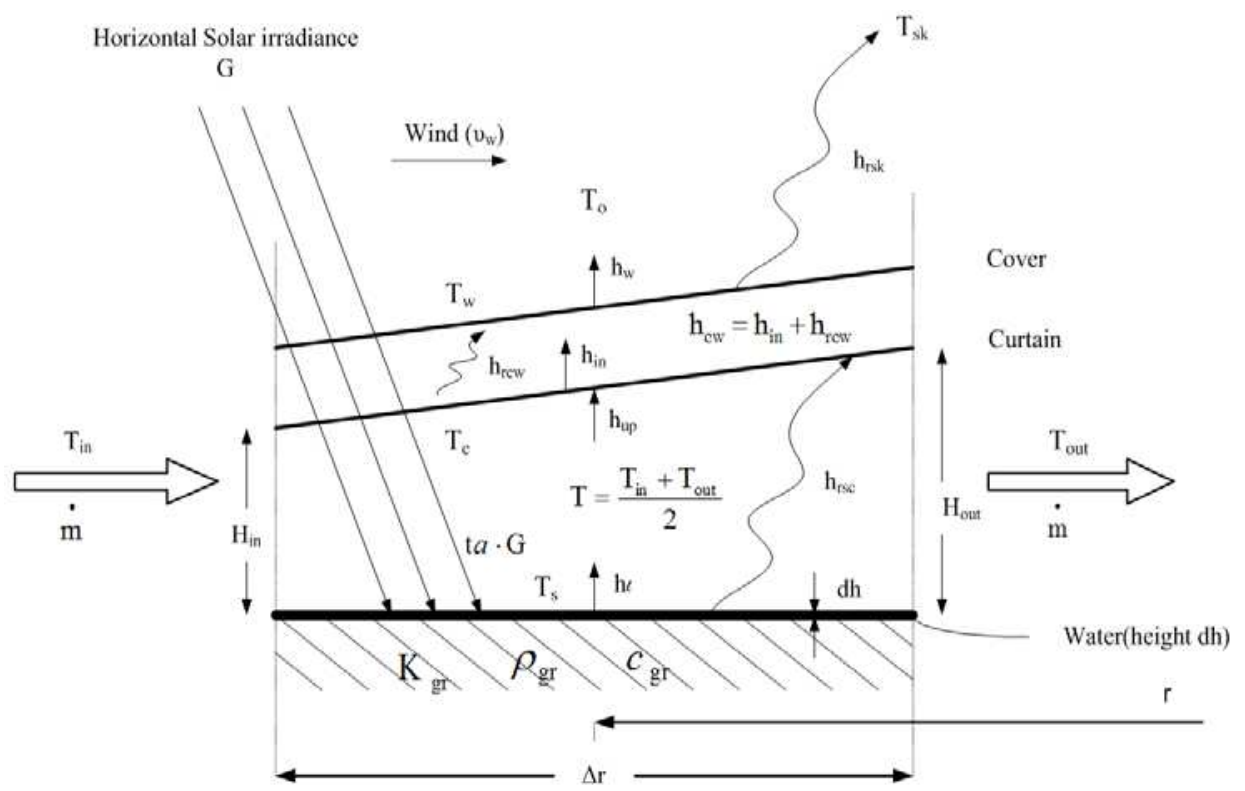

Fig. 12. The cut of a circular sector of a double glazing circular solar collector

The $m^{\text {th }}$ circular sector $(m=1$ up to $M)$ will have a width $\Delta r=\left(D_{c}-D_{\text {in }}\right) / M$, an average radius $r_{m}=D c / 2-\Delta r \cdot(m 1-1 / 2)$ and an average height $H_{m}=\left(H_{i n, m}+H_{e x, m}\right) / 2$.

For a linear variation of the roof height $\mathrm{H}_{\mathrm{m}}=\mathrm{Hin}+\left(\right.$ Hout-Hin) $\cdot(\mathrm{m}-1 / 2) / \mathrm{M}$, where $\mathrm{D}_{\mathrm{c}}=$ solar collector diameter and $\mathrm{D}_{\text {in }}=$ Final internal diameter of the solar collector.

These consecutive circular sectors, for the moving air stream of mass flow $\dot{m}$, are special tubes of nearly parallel flat surfaces and therefore they have equivalent average diameters $\mathrm{d}_{\mathrm{e}, \mathrm{m}}=2 * \mathrm{H}_{\mathrm{m}}$.

As the ambient air moves towards the entrance of the first circular sector it is assumed that its temperature $T_{0}$ increases to $T_{0}+d T$ due to the ground heat transfer convection to inlet air, around the solar collector. As an approximation dT is estimated to $0.5^{\circ} \mathrm{K}$. 
The exit temperature of the first sector is the inlet temperature for the second etc. and finally the exit temperature of the final $\mathrm{M}^{\text {th }}$ sector is the $\mathrm{T}_{03}$, i.e. the inlet stagnation temperature to the air turbines.

The solar chimney heat transfer analysis during a daily 24 hours cycle, is too complicated to be presented analytically in this text however we can use the results of this analysis in order to have a clear picture of the operational characteristics of the SAEPs. Using the code of the heat transfer analysis for moving mass flow $\dot{m}_{M}$, the daily variation of the exit temperature $\mathrm{T}_{03}$ can be calculated. Using these calculated daily values of the $\mathrm{T}_{03}$ and by the thermodynamic cycle analysis for the optimal mass flow $\dot{m}_{M}$ the daily power profile of the electricity generation can be calculated.

With this procedure the 24 hour electricity generation power profile of a SAEP with a solar collector of surface area $A_{c}=10^{6} \mathrm{~m}^{2}$ and a FSC of $\mathrm{H}=800 \mathrm{~m}$ height and $\mathrm{d}=40 \mathrm{~m}$ internal diameter for an average day of the year has been calculated. The SAEP is installed in a place with annual horizontal solar irradiation $\mathrm{W}_{\mathrm{y}}=1700 \mathrm{KWh} / \mathrm{m}^{2}$.

In the following figure three electric power profiles are shown with or without artificial thermal storage.

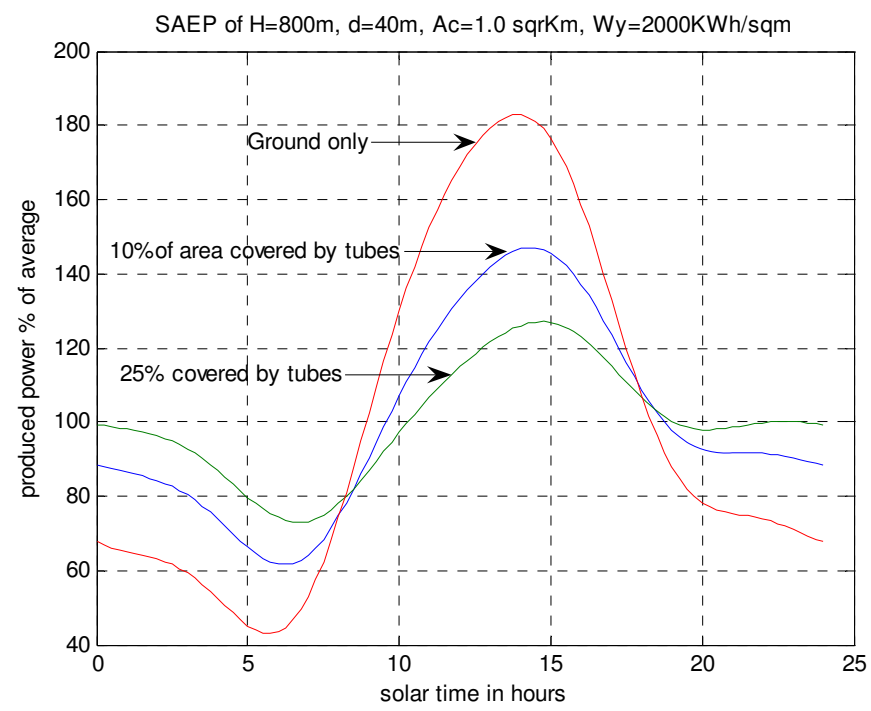

Fig. 13. The average daily SAEP's electricity generating profiles

The relatively smooth profile shows the electric power generation when only the ground acts as a thermal storage means. While the smoother profiles are achieved when the greenhouse is partly covered ( $\sim 10 \%$ or $\sim 25 \%$ of its area) by plastic black tubes of $35 \mathrm{~cm}$ of diameter filled with water, i.e. there is also additional thermal storage of an equivalent water sheet of $35 \cdot \Pi / 4=27.5 \mathrm{~cm}$ on a small part of the solar collector.

The daily profiles show that the SAEP operates 24 hours/day, due to the greenhouse ground (and artificial) thermal storage. That is a considerable benefit of the FSC technology compared to the rest solar technologies and the wind technology which if they are not equipped with energy mass storage systems they can not operate continuously. 
As shown in the produced curves on the previous figure, with a limited $(\sim 10 \%)$ of the greenhouse ground covered by plastic tubes $(35 \mathrm{~cm})$ filled with water, the maximum daily power is approximately $140 \%$ of its daily average, or the daily average is $70 \%$ of its maximum power.

Taking into consideration the seasonal power alteration and assuming that the average annual daily irradiation at a typical place is approximately $70 \%$ of the average summer daily irradiation, the annual average power can be estimated as a percentage of the maximum power production (at noon of summertime) as the product of 0.77·0.70=0.49.

The maximum power is equal to the rating of the power units of the SAEP (Air turbine, electric generator, electric transformer etc.), while the average power multiplied by 8760 hours of the year defines the annual electricity generation. Therefore the capacity factor of a SAEP equipped with a moderate artificial thermal storage can be as high as $\sim 49 \%$.

Without any artificial thermal storage the average daily power is approximately 0.55 of its maximum thus the capacity factor is $\sim 37 \%(0.55 \cdot 0.70 \approx 0.385)$.

This means that in order to find the annual energy production by the SAEP we should multiply its rating power by $\sim 3250 \div 4300$ hours. However we should take into consideration that the SAEPs are operating continuously $(24 \times 365)$ following a daily and seasonal varying profile.

\section{The major parts and engines of Floating Solar Chimney technology}

\subsection{The solar collector (Greenhouse)}

The solar collector can be an ordinary circular greenhouse with a double glazing transparent roof supported a few meters above the ground. The periphery of the circular greenhouse should be open to the ambient air. The outer height of the greenhouse should be at least 2 meters tall in order to permit the entrance of maintenance personnel inside the greenhouse. The height of the solar collector should be increased as we approach its centre where the FSC is placed. As a general rule the height of the transparent roof should be inversely proportional to the local diameter of the circular solar collector in order to keep relatively constant the moving air speed. The circular greenhouse periphery open surface can be equal or bigger than the FSC cut area.

Another proposal with a simpler structure and shape the greenhouse can be of a rectangular shape of side DD. The transparent roof could be made of four equal triangular transparent roofs, elevating from their open sides towards the centre of the rectangle, where the FSC is placed. Thus the greenhouse forms a rectangular pyramid.

The previous analysis is approximately correct and can be figured out by using an equivalent circular greenhouse external diameter $D_{c} \approx D D \cdot \sqrt{4 / \pi}$.

The local height of each inclined triangular roof is almost inversely proportional to the local side of the triangle in order to secure constant air speed.

Both solar collector structures are typical copies of ordinary agriculture greenhouses although they are used mainly for warming the moving stream of air from their periphery towards the centre where the FSC of the SAEP is standing. Such greenhouses are appropriate for FSC technology application combined with special agriculture inside them. In desert application of the FSC technology the solar collectors are used exclusively for air warming. Also in desert or semi desert areas the dust on top of the transparent roofs of the conventional greenhouses could be a major problem. The dust can deteriorate the transparency of the upper glazing and furthermore can add unpredictable weight burden on 
the roof structure. The cleaning of the roof with water or air is a difficult task that can eliminate the desert potential of the FSC technology.

Furthermore in desert or semi-desert areas the construction cost of the conventional solar collector (a conventional greenhouse) could be unpredictably expensive due to the unfavourable working conditions on desert sites.

For all above reasons another patented design of the solar collectors has been proposed by the author.The proposed modular solar collector, as has been named by the author, will be evident by its description that it is a low cost alternative solar collector of the circular or rectangular conventional greenhouse which can minimize the works of its construction and maintenance cost on site.

We can also use and follow the ground elevation on site, and put the FSC on the upper part of the land-field therefore the works on site for initial land preparation will be minimized.

The greenhouse will be constructed as a set of parallel reverse- $V$ transparent tunnels made of glass panels as shown in the next figure (14). The maximum height of the air tunnel should be at least $190 \mathrm{~cm}$ in order to facilitate the necessary works inside the tunnel, as it is for example the hanging of the inner crystal clear curtains.

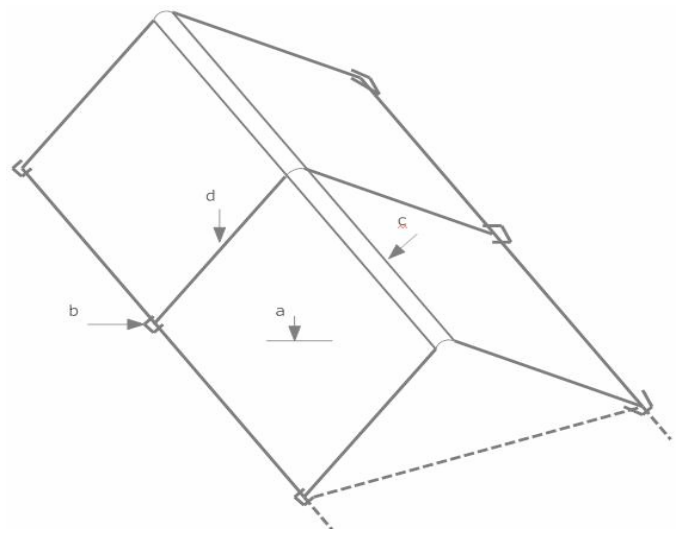

Fig. 14. A part of the triangular tunnel of two panels (a)glass panel, (b)ground support, (c)glass panel connector (d)glass plastic separator

An indicative figure of a greenhouse made of ten air tunnels is shown in next figure. Among the parallel air tunnels it is advisable that room should be made for a corridor of $30-40 \mathrm{~cm}$ of width for maintenance purposes.

By above description it is evident that the modular solar collector is a low cost alternative of a conventional circular greenhouse for the FSC technology in desert or semi-desert areas that minimize the works on site and lower the construction costs of the solar collector and its SAEP. Furthermore the dust problem is not in existence because the dust slips down on the inclined triangular glass panels.

The average annual efficiency of the modular solar collector made by a series of triangular warming air tunnels with double glazing transparent roofs is estimated to be even higher than $50 \%$. Thus its annual efficiency will follow the usual diagram of efficiency (or it will be even higher).

The total cut area of all the triangular air tunnels should be approximately equal to the cut area of the FSC for constant air speed. The central air collecting corridor cut should also follow the constant air speed rule for optimum operation and minimum construction cost. 


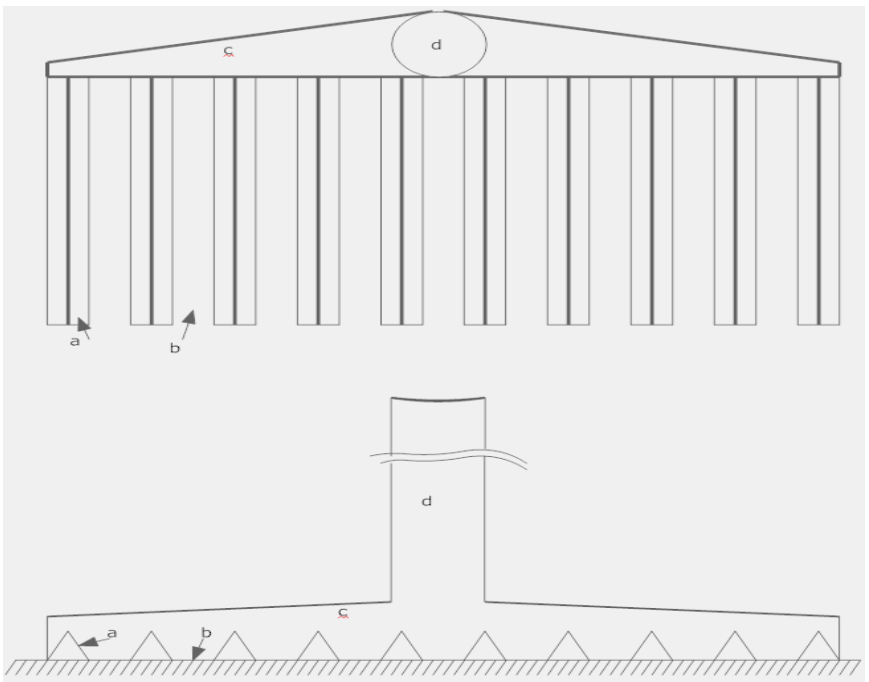

Fig. 15. Modular solar collector with ten air tunnels (a)Triangular tunnel, (b)Maintenance corridor (c)Central air collecting tube, (d)FSC

\subsection{The Floating Solar Chimney (FSC)}

A small part of a typical version of the FSC on its seat is taking place in the figure(16) below.

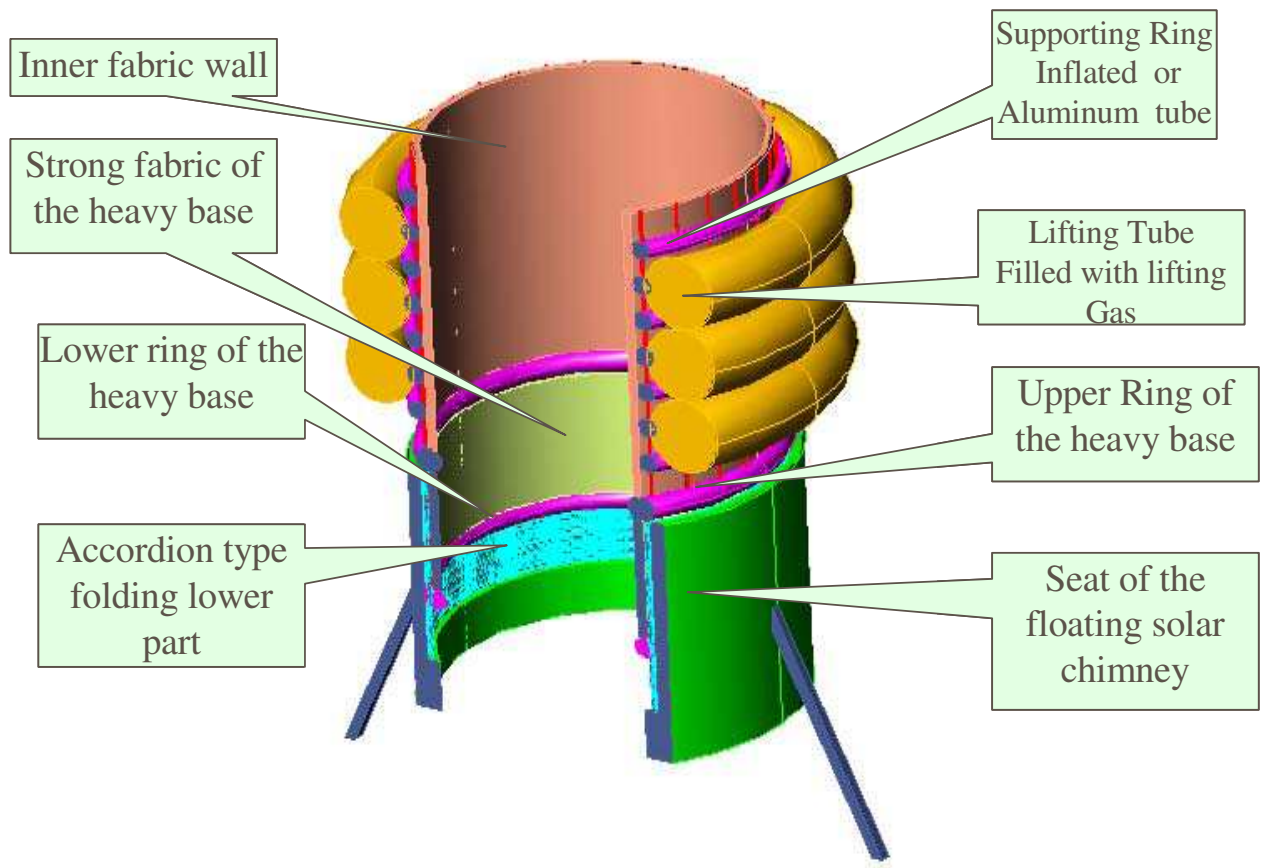

Fig. 16. A small part of a typical version of the FSC on its seat 
The over-pressed air tubes of the fabric structure retain its cylindrical shape. While the lifting tubes (usually filled with $\mathrm{NH}_{3}$ ) supply the structure with buoyancy in order to take its upright position without external winds. Both tubes can be placed outside the fabric wall as they are shown in the figure or inside the fabric wall. When the tubes are inside the fabric core they are protected by the UV radiation and the structure has a more compact form for the encountering of the external winds unpredictable behavior. But inside the warm air friction losses are increased and in order to have the same internal diameter the external diameter of the fabric core should be greater. In the first demonstration project both shapes could be tested in order that the best option is chosen.

Therefore the FSCs of the SAEPs are free standing fabric structures and due to their inclining ability they can encounter the external winds. See the next indicative figure (17) describing its tilting operation under external winds.

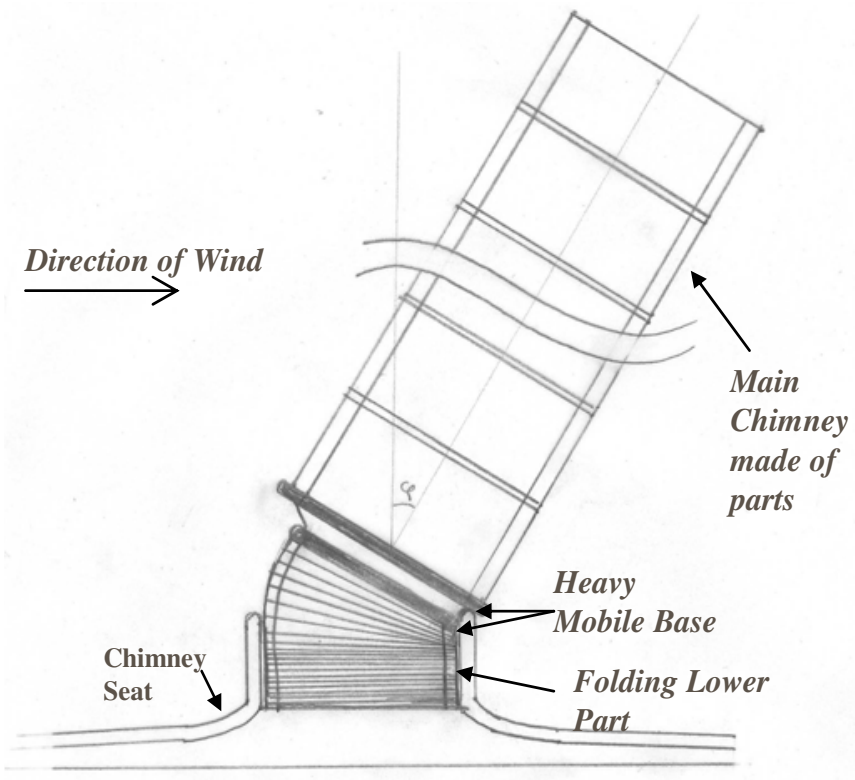

Fig. 17. Tilting operation of the FSC under external winds

However in areas with annual average strong winds the operating heights of the inclining fabric structures are decreasing. The following figure (18) presents the operating height loss of the FSCs as function of the average annual wind speed, for Weibull average constant $k \approx 2.0$. The net buoyancy of the FSC is such that will decline $60^{\circ}$ degrees when a wind speed of $10 \mathrm{~m} / \mathrm{sec}$ appears.

For example using the diagram in figure (18), for an average wind speed of $3 \mathrm{~m} / \mathrm{sec}$ and a net lift force assuring a $50 \%$ bending for a wind speed of $10 \mathrm{~m} / \mathrm{sec}$, the average operating height decrease is only $3.7 \%$.

As a result we can state that the best places for FSC technology application are the places of high average horizontal solar irradiation, low average winds and limited strong winds. The mid-latitude desert and semi-desert areas, that exist in all continents, combine all these properties and are excellent places for large scale FSC technology application. 


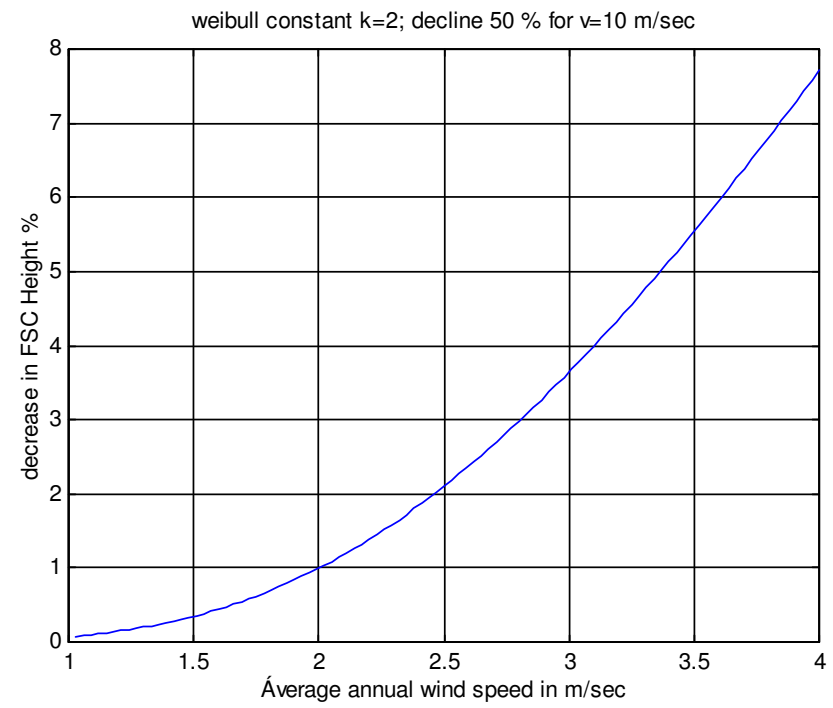

Fig. 18. FSC's operating height average decrease under external winds.

\subsection{The air turbines}

The air turbines of the SAEPs are either of horizontal axis placed in a circular pattern around their FSCs or with normal axis placed inside the FSCs (near the bottom). The later case with only one air turbine is most appropriate for the FSC technology, while the former is more advisable for concrete solar chimney technology applications.

The air turbines of the solar chimney technology are caged (or ducted) air turbines. These air turbines are not similar to wind turbines that transform the air kinetic energy to rotational energy, therefore their rotational power output depends on the wind speed or the air mass flow. The caged air turbines transform the dynamic energy of the warm air, due to their buoyancy, to rotational. Therefore their rotational power output does not depend on the mass flow only but on the product of the mass flow and the pressure drop on the air turbine. Therefore the warm air mass flow, as we have noticed already, is possible to remain approximately constant during the daily operation (in order that an optimal operation is achieved) while its rotational power and its relative electric power output vary during the daily cycle. The varying quantity is the pressure drop of the air turbine. This pressure drop depends on the warm air temperature i.e. the warm air proportional buoyancy and the FSC height.

The air turbines are classified according to the relation between their mass flows and their pressure drops. The wind turbines are class A turbines (large mass flow small pressure drop). The useful classes for solar chimney application are the class B and C. The class B are the caged air turbines with lower pressure drop and relatively higher mass flow and made without inlet guiding vanes, while the class $C$ air turbines are with higher pressure drops and relatively lower mass flows and should be made of inlet guiding vanes in order that optimal efficiency is achieved.

Considering that the floating or concrete solar chimney SAEPs can have the same heights (between $500 \mathrm{~m} \div 1000 \mathrm{~m}$ ) the defining factor for air turbines with or without inlet guiding vanes is the solar collector diameter. 
For the expensive concrete solar chimney the respective solar collectors are made with high diameters in order to minimize the construction cost of their SAEPs. While the low cost floating solar chimneys can be designed with smaller solar collectors for minimal cost and optimal operation.

The diameters of the solar collectors are proportional to the increase of the warm air temperatures $\Delta \mathrm{T}=\mathrm{T}_{03}-\mathrm{T}_{0}$, thus proportional also to the buoyancies and to the pressure drops on the air turbines.

Therefore the Floating Solar Chimney SAEPs can be designed with air turbines of class B (i.e. without inlet guiding vanes). These caged air turbines are lower cost units per generated electricity KWh in comparison with class $\mathrm{C}$ air turbines which are appropriate for concrete solar chimney SAEPs.

\subsection{The electric generators}

There are two types or electric generators which can be used in SAEPs, the synchronous and the induction or asynchronous electric generators.

The synchronous electric generators for FSC technology should have a large number of polepairs pp. The frequency of the generated electricity by the multi-pole synchronous electric generator should be equal to the grid frequency $\mathrm{f}$.

The generated electricity frequency of the synchronous generators $f_{e l}$ is proportional to its rotational frequency $f_{g}$ i.e. $f_{e l}=p p \cdot f_{g}$. Thus in case of varying $f_{g}$ an electronic drive is necessary, for adjusting the generated electric frequency $f_{e l}$ to the grid electric frequency $f$.

A multi-pole (high value of $\mathrm{pp}$ ) synchronous electric generator combined with an electronic drive can be a reasonable solution in order to avoid the adjusting gear box.

In order to control the set to operate the whole SAEP under optimal conditions we either control its electronic drive unit or its air turbine blade pitch.

The induction generators are of two types. The squirrel cage and the double fed or wound rotor induction generators. The squirrel cage induction generators rotate with frequencies close to their synchronous respective frequencies $\mathrm{f} / \mathrm{pp}$ defined by the grid frequency and their pole-pairs. For given pole-pairs (for example for four pole caged induction generators $\mathrm{pp}=2$ ) the induction generator should engage itself to the air turbine through an appropriate gear box that is multiplying its rotational frequency in order that the generator rotational speed matches to the frequency $(\mathrm{f} / \mathrm{pp}) \cdot(1+\mathrm{s})$, where $\mathrm{s}$ is the absolute value of the slip and it is a small quantity in the range of 0.01 for large generators.

The electric power output of the squirrel cage induction generator is approximately proportional to the absolute value of the slip s near their operating point. Thus even high power variations can be absorbed with small rotational frequency variations. Therefore the squirrel cage induction generators engaged to the air turbines with proper gear boxes are supplying the grid always with the proper electric frequency and voltage without any electronic control. The only disadvantage of the squirrel cage induction generators is that they always produce an inductive reactive power. This reactive power should be compensated using a parallel set of capacitors creating a capacitive reactive power.

The wound rotor or doubly fed induction generators are characterized by the fact that their rotors are supplied with a low frequency electric current. With proper control of the voltage and frequency of the rotor supply we can make them operate as zero reactive power units. The electronic system supplying the rotor with low frequency current is a power electronic unit of small power output ( $3 \%$ of the power output of the generator). However the doubly fed induction generators with these small electronic supplies of their rotors are more 
expensive than the squirrel cage induction generators with reactive power compensating capacitors.

The SAEPs with normal axis air turbines have enough space underneath the air turbine to accommodate a large diameter multi-pole generator with a large number of pole pairs in order to avoid the rotation frequency adjusting gear box.

I believe that the large scale application of the FSC technology will boost the research and production of large diameter multi-pole squirrel caged or wound rotor induction generators in order to avoid the sensitive and expensive adjusting gear boxes and to lower the cost of large electronic drives of multi-pole synchronous generators.

\subsection{The gear boxes}

The gear box is a essential device for adjusting the frequency of the rotation of the air turbines $\mathrm{f}_{\mathrm{T}}$ to the electric frequency $\mathrm{f}$ of the grid through the relation

$\mathrm{f}=\mathrm{pp} \cdot \mathrm{f}_{\mathrm{T}} \cdot \mathrm{rt}$. The $\mathrm{rt}$ is the rate of transmission of the gear box i.e the generator rotates with frequency $\mathrm{f}_{\mathrm{g}}=\mathrm{f}_{\mathrm{T}} \cdot \mathrm{rt}$.

When conventional electric generators with a few pole pairs (low pp) are used, as electricity generating units, gear boxes with a proper rate of transmission rt are necessary. However if multi-pole electric generators are used with high pole-pair values $\left(\mathrm{pp}_{\mathrm{h}}\right)$ then the gear boxes can be avoided (if $\mathrm{pp}_{\mathrm{h}}=\mathrm{pp} \cdot \mathrm{rt}$ ).

The gear boxes are mechanical devices made of gears of various diameters and combinations in order to transform their the mechanical rotation incoming and out-coming characteristics (i.e.the frequency of rotation $\mathrm{f}_{\text {in }}, \mathrm{f}_{\text {out }}$ and the torque $\mathrm{Tq} \mathrm{q}_{\text {in }}$ and $\mathrm{Tq} \mathrm{q}_{\text {out }}$ ) by the relations $\mathrm{f}_{\text {in }} / \mathrm{f}_{\text {out }}=\mathrm{Tq} \mathrm{q}_{\text {out }} / \mathrm{Tq} \mathrm{q}_{\text {in }}=\mathrm{rt}=$ rate of transmission.

The gears demand a continuous oil supply and have a limited life cycle. Thus the gear boxes being huge and heavy devices of high maintenance and sensitivity, if possible they should not be preferred.

The electric power production by the SAEPs, is calculated as a function of the inlet air speed $v$ (i.e. the air mass $\dot{m}$ ) in the air turbines by a relation of the form:

$$
P=\dot{\mathrm{m}} \cdot c_{p} \cdot\left(\mathrm{T}_{03}-\mathrm{T}_{03 \mathrm{te}}\right)=\dot{\mathrm{m}} \cdot c_{p} \cdot\left(\mathrm{T}_{03}-\mathrm{T}_{4}-\mathrm{C}_{2} \cdot \mathrm{T}_{4}^{2}-\frac{\mathrm{g} \cdot \mathrm{H}}{c_{\mathrm{p}}}\right)
$$

Where $\mathrm{T}_{\mathrm{O} 3}, \mathrm{~T}_{\mathrm{O} 3 \mathrm{te}}$ are functions of mass flow $\dot{m}$ and FSC top exit temperature $\mathrm{T}_{4}$. We have shown that $\mathrm{T}_{4}$ is the (appropriate) root of a fourth order polynomial equation:

$$
w_{1} \cdot \mathrm{T}_{4}^{4}+w_{2} \cdot \mathrm{T}_{4}^{3}+w_{3} \cdot \mathrm{T}_{4}^{2}+w_{4} \cdot \mathrm{T}_{4}+w_{5}=0
$$

where $\mathrm{w}_{1}, \mathrm{w}_{2}, \mathrm{w}_{3}, \mathrm{w}_{4}$ and $\mathrm{w}_{5}$ are functions of the geometrical, the thermal and ambient parameters of the SAEP, the air turbine efficiency $\eta_{\mathrm{T}}$ and the equivalent horizontal solar irradiance G.

The mass flow $\dot{m}$ and the warm air speed $v$ are proportional $\left(\dot{m}=\rho \cdot A_{t} \cdot v\right)$ Thus:

\section{$\mathrm{P}=$ Function $(\mathrm{v})$}

The efficiency of the air turbine is in general a function of the ratio $\mathrm{v} / \mathrm{v}$ tip i.e. $\eta_{\mathrm{T}}\left(\mathrm{v} / \mathrm{v}_{\text {tip }}\right)$ where $\mathrm{v}_{\text {tip }}$ is the blades' end rotational speed.

The air turbines of the SAEPs with their geared electric generators are generating electric power following the air turbine characteristics given by the two operating functions $\mathrm{P}(\mathrm{v})$, 
and $\eta_{\mathrm{T}}\left(\mathrm{v} / \mathrm{v}_{\text {tip }}\right)$. Considering that $\mathrm{v}$ tip $=\Pi \cdot \mathrm{f}_{\mathrm{T}} \cdot \mathrm{d}_{\mathrm{T}}$, where $\mathrm{f}_{\mathrm{T}}$ is the air turbine frequency of rotation and $\mathrm{d}_{\mathrm{T}}$ the turbine diameter.

The electric frequency for the geared electric generators is equal to $f_{n}$ where: $f_{n}=f_{t} \cdot r t \cdot p p$, rt is the gear box transmission ratio and pp the number of their pole pairs. Hence:

$$
v_{\text {tip }}=\frac{\pi \cdot d_{T} \cdot f_{n}}{r t \cdot p p}
$$

For optimal power production by a SAEP, for an average solar irradiance $G$, the maximum point of operation of $\mathrm{P}(\mathrm{v})$ should be reached for an air speed $\mathrm{v}$ for which the efficiency $\eta_{\mathrm{T}}\left(\mathrm{v} / \mathrm{v}_{\text {tip }}\right)$ is also maximum.

The value of $\mathrm{v}_{\mathrm{m}}$ for maximum electric power can be defined by the SAEP operating function for $\eta_{\mathrm{T}}=$ constant (usually equal to 0.8 ) and a given solar irradiance $\mathrm{G}$.

The value of the ratio $\left(v / v_{\text {tip }}\right)_{m}$ for maximum air turbine efficiency can be defined by the turbine efficiency function $\eta_{\mathrm{T}}\left(\mathrm{v} / \mathrm{v}_{\text {tip }}\right)$.

Thus the appropriate $v_{\text {tip }}$ is defined by the relation:

$$
v_{\text {tip }, m}=\frac{v_{m}}{\left(v / v_{t i p}\right)_{m}}
$$

Where the index m means maximum power or efficiency.

Thus for $v_{\text {tip, }}$ the maximum power production under the given horizontal solar irradiance $G$ is generated. Taking into account that $v_{\text {tip }}$ and $f_{n}$ are proportional, $f_{n}$ should vary with the horizontal solar irradiance $G$.

However as we have stated the mass flow for maximum power output by the SAEP is slightly varying with varying $G$, thus we can arrange the optimum control of the SAEP for the average value of $G$.

A good choice for this average $G$ is a value of $5 \div 10 \%$ higher than the annual average $G_{y, a v}$, defined by the relation $G_{y, a v}=W_{y} / 8760$.

Following the previous procedure for the proposed $G$, if the air turbine efficiency function $\eta_{\mathrm{T}}\left(\mathrm{v} / \mathrm{v}_{\text {tip }}\right)$ is known or can be estimated, the value of $v_{\text {tip,m }}$ can be calculated.

The frequency $f$ of the produced A.C. will follow $f_{n}$ by the relation $f=(1+s) \cdot f_{n}$, where $s$ is the absolute value of the operating slip. Taking into consideration that the absolute value of slip $\mathrm{s}$, for large induction generators, is less than $1 \%, \mathrm{f} \approx \mathrm{f}_{\mathrm{n}}$.

Thus the gear box transmission ratio will be defined by the approximate relation:

$$
r t \approx \frac{\pi \cdot d_{T} \cdot f}{v_{t i p, m} \cdot p p}
$$

If the air turbine efficiency function $\eta_{\mathrm{T}}(\mathrm{v} / \mathrm{v}$ tip $)$ is not known we can assume that for caged air turbines without inlet guiding vanes their maximum efficiency is achieved for $v_{\text {tip }, \mathrm{m}}=(6 \div 8) \cdot \mathrm{v}$.

Thus:

$$
r t \approx \frac{\pi \cdot d_{T} \cdot f}{(6 \cdots 8) \cdot v_{m} \cdot p p}
$$


Where: $\mathrm{v}_{\mathrm{m}}=$ the air speed for maximum efficiency of the SAEP (derived by the SAEP basic equation for the chosen value of $\mathrm{G}$ ), $\mathrm{d}_{\mathrm{T}}=$ the caged air turbine diameter (smaller by $10 \%$ of the FSC diameter usually), $\mathrm{f}=$ the grid frequency (usually $50 \mathrm{sec}^{-1}$ ), $\mathrm{pp}=2$ (usually the generators are four pole machines).

\section{Dimensioning and construction cost of the Floating Solar Chimney SAEPS}

\subsection{Initial dimensioning of Floating Solar Chimney SAEPs}

The floating solar chimneys are fabric structures free standing due to their lifting balloon tube rings filled with a lighter than air gas. The inexpensive $\mathrm{NH}_{3}$ is the best choice as lifting gas for the FSCs. As we will see later the FSCs are low cost structures, in comparison with the respective concrete solar chimneys.

The annual electricity generation by the SAEPs $(\mathrm{E})$ is proportional to their FSC's height $(\mathrm{H})$, their solar collector surface area $\left(\mathrm{A}_{\mathrm{c}}\right)$ and the annual horizontal irradiation at the place of their installation $W_{y}$ i.e. $E=c \cdot H \cdot A_{c} \cdot W_{y}$.

As for the concrete solar chimney SAEPs, due to their concrete solar chimneys high cost, it is obvious that in order to minimize their overall construction cost per produced KWh, it is preferable to use one solar chimney, of height $\mathrm{H}$ and internal diameter $\mathrm{d}$, and a large solar collector of surface area $\mathrm{A}_{\mathrm{c}}$.

In case of the floating solar chimney SAEPs, generating the same annual amount of electricity, a farm of N similar SAEPs should be used. Their FSCs will have the same height $(\mathrm{H})$ and their solar collectors a surface area $\mathrm{A}_{\mathrm{c}} / \mathrm{N}$. If the internal diameters of these FSCs are $d_{F S C} \approx d / \sqrt{N}$ then both Power Plants they will have the same efficiency and power production. Usually $d_{F S C}>d / \sqrt{N}$ therefore the FSC farm has higher efficiency and generates more electricity than the concrete solar chimney SAEP for the same solar collector area.

We have several benefits by using farms of FSC technology as for example:

- The handling of FSC lighter than air fabric structures is easy if their diameters are smaller. The diameter $d_{F S C}$ should not be less than $1 / 20$ of FSC height $\mathrm{H}$.

- This choice will give us the benefit of using existing equipment (electric generators, gear-boxes, etc.) already developed for the wind industry.

- The smaller surface areas of the solar collectors will decrease the average temperature increase $\Delta \mathrm{T}$ of the moving air mass, and consequently it is advisable that simpler and lower cost air turbines should be used (class B instead of class $C$ air turbines i.e. caged air turbines without inlet guiding vanes).

The following restrictions are prerequisite for a proper dimensioning of the Floating Solar Chimney SAEPs.

- The FSC height $\mathrm{H}$ should be less than $800 \mathrm{~m}$.

- Their internal diameter should be less than $40 \mathrm{~m}$

- The solar collector active area should be less than $100 \mathrm{Ha}$ (i.e. $10^{6} \mathrm{~m}^{2}$ )

If the solar collectors are equipped with artificial thermal storage the SAEP will have a rating power of $\mathrm{P}_{\mathrm{r}}=\mathrm{W}_{\mathrm{y}} \cdot \eta \cdot \mathrm{A}_{\mathrm{c}} / 4300$. For maximum height $800 \mathrm{~m}$, and $\mathrm{d}=40 \mathrm{~m}$ the SAEP annual efficiency is $\eta \approx 1 \%$. In desert places $W_{y}$ can be as high as $2300 \mathrm{KWh} / \mathrm{m}^{2}$. Thus $P_{\mathrm{r}}$ for the maximum solar collector surface area of $10^{6} \mathrm{~m}^{2}$ is less than $5 \mathrm{MW}$.Generators and respective gear-boxes up to 5MW are already in use for wind technology. Furthermore if we choose an internal diameter of $40 \mathrm{~m}$ for the FSC, it can be proven that for rating power less than $5 \mathrm{MW}$, 
the optimal air turbine should be of class B, i.e. without the inlet guiding vanes. The air turbine will be placed onto the normal axis inside the bottom of the FSC. A useful notice concerning the dimensioning of the SAEPs is that for constant FSC height $\mathrm{H}$, rating power and annual horizontal irradiation the solar collector equivalent diameter $\mathrm{D}_{c}$ and the FSC internal diameter $\mathrm{d}$ are nearly proportional.Let us apply the dimensioning rules in the case of desert SAEPs, considering for example that the annual horizontal irradiation is not less than $2100 \mathrm{KWh} / \mathrm{m}^{2}$.Let us consider that the FSC height $\mathrm{H}$ is varying, while the solar collector area is remaining constant to $1.0 \mathrm{Km}^{2}$ and the FSC internal diameter is also constant and equal to $40 \mathrm{~m}$. The rating power of the respective SAEPs, with artificial thermal storage, is shown on the following table(2).

\begin{tabular}{|c|c|c|c|}
\hline Solar collector area in $\mathrm{Km}^{2}$ & $\begin{array}{c}\text { FSC internal } \\
\text { diameter } \mathrm{d} \text { in } \mathrm{m}\end{array}$ & $\begin{array}{c}\text { FSC height } \\
\mathrm{H} \text { in } \mathrm{m}\end{array}$ & $\begin{array}{c}\text { Rating power } \\
\mathrm{P}_{\mathrm{r}} \text { in MW }\end{array}$ \\
\hline 1.0 & 40 & 180 & 1.0 \\
\hline 1.0 & 40 & 360 & 2.0 \\
\hline 1.0 & 40 & 540 & 3.0 \\
\hline 1.0 & 40 & 720 & 4.0 \\
\hline 1.0 & 40 & 800 & 4.5 \\
\hline
\end{tabular}

Table 2. Dimensions and rating of SAEPs of $1 \mathrm{Km}^{2}$ with artificial thermal storage

In the following table (3) initial dimensions of the SAEPs of FSC height 720m installed on the same area for rating power $1 \mathrm{MW}, 2 \mathrm{MW}, 3 \mathrm{MW}$ and $4 \mathrm{MW}$ are shown.

\begin{tabular}{|c|c|c|c|}
\hline $\begin{array}{c}\text { Solar collector area in } \\
\mathrm{Km}^{2}\end{array}$ & $\begin{array}{c}\text { Minimum FSC internal } \\
\text { diameter } \mathrm{d} \text { in } \mathrm{m}\end{array}$ & $\begin{array}{c}\text { FSC height } \mathrm{H} \\
\text { in } \mathrm{m}\end{array}$ & $\begin{array}{c}\text { Rating power } \\
\mathrm{P}_{\mathrm{r}} \text { in MW }\end{array}$ \\
\hline 0.25 & 36 & 720 & 1.0 \\
\hline 0.50 & 36 & 720 & 2.0 \\
\hline 0.75 & 36 & 720 & 3.0 \\
\hline 1.0 & 36 & 720 & 4.0 \\
\hline
\end{tabular}

Table 3. Dimensions and rating of SAEPs of $720 \mathrm{~m}$ height with artificial thermal storage

\subsection{Estimating the direct construction cost of Floating Solar Chimney SAEPs}

The direct construction cost of a Floating Solar Chimney SAEP with given dimensions is the sum of the costs of its three major parts, the solar collector cost ( $\left.\mathrm{C}_{\mathrm{SC}}\right)$, the FSC cost ( $\left.\mathrm{C}_{\mathrm{FSC}}\right)$ and the Air turbines gear boxes and generators cost $\left(\mathrm{C}_{\mathrm{TG}}\right)$. The construction cost of the solar collector is proportional to its surface area. A reasonable rough estimate of modular solar collectors including the cost of their collecting corridors is:

$$
\mathrm{C}_{\mathrm{SC}}=6.0 \cdot \mathrm{A}_{\mathrm{c}} \text { in } \mathrm{EURO}\left(\mathrm{A}_{\mathrm{c}} \text { in } \mathrm{m}^{2}\right)
$$

The construction cost of the FSC is the sum of the cost of its fabric lighter than air cylinder, and the cost of the heavy base, the folding accordion and the seat. A reasonable rough estimation of above costs is: 


$$
\mathrm{C}_{\mathrm{FSC}}=60 \cdot \mathrm{H} \cdot \mathrm{d}+300 \cdot \mathrm{d}^{2} \text { in } \mathrm{EURO}(\mathrm{H}, \mathrm{d} \text { in } \mathrm{m})
$$

The construction cost of the Turbo-Generators is proportional to the rating power $\mathrm{P}_{\mathrm{r}}$ of the SAEP a reasonable rough estimation for this cost is:

$$
\mathrm{C}_{\mathrm{TG}}=300 \cdot \mathrm{P}_{\mathrm{r}} \text { in } \mathrm{EURO}\left(\mathrm{P}_{\mathrm{r}} \text { in } \mathrm{KW}\right)
$$

The estimating rough figures are reasonable for SAEPs of rating power of $1 \div 5 \mathrm{MW}$. Any demonstration SAEP and maybe the first few operating SAEPs possible will give us a construction cost up to $\sim 100 \%$ higher than the estimated by the previous rough formulae but gradually the direct construction cost of the SAEPs should have even lower construction costs than estimated by the given rough formulae. In the following tables $(4,5)$ the construction costs of the previously dimensioned SAEPs are given.

Taking into consideration that the rating power multiplied by 4300 hours (for solar collectors reinforced with artificial thermal storage) will give the annual electricity generation, the construction cost per produced KWh/year is also presented in the tables $(4,5)$.

\begin{tabular}{|c|c|c|c|c|c|}
\hline $\begin{array}{c}\text { Solar } \\
\text { collector } \\
\text { area in } \mathrm{Km}^{2}\end{array}$ & $\begin{array}{c}\text { FSC } \\
\text { internal } \\
\text { diameter d } \\
\text { in } \mathrm{m}\end{array}$ & $\begin{array}{c}\text { FSC } \\
\text { height } \mathrm{H} \\
\text { in } \mathrm{m}\end{array}$ & $\begin{array}{c}\text { Rating } \\
\text { power } \mathrm{P}_{\mathrm{r}} \\
\text { in MW }\end{array}$ & $\begin{array}{c}\text { Construction } \\
\text { cost in million } \\
\text { EURO }\end{array}$ & $\begin{array}{c}\text { Construction } \\
\text { cost in EURO } \\
\text { per produced } \\
\text { KWh/year }\end{array}$ \\
\hline 1.0 & 40 & 180 & 1.0 & 7.2 & 1.54 \\
\hline 1.0 & 40 & 360 & 2.0 & 8.0 & 0.85 \\
\hline 1.0 & 40 & 540 & 3.0 & 8.7 & 0.62 \\
\hline 1.0 & 40 & 720 & 4.0 & 9.4 & 0.50 \\
\hline 1.0 & 40 & 800 & 4.5 & 9.8 & 0.47 \\
\hline
\end{tabular}

Table 4. Direct construction cost of various SAEPs

\begin{tabular}{|c|c|c|c|c|c|}
\hline $\begin{array}{c}\text { Solar } \\
\text { collector } \\
\text { area in Km² }\end{array}$ & $\begin{array}{c}\text { Minimum } \\
\text { FSC internal } \\
\text { diameter d } \\
\text { in m }\end{array}$ & $\begin{array}{c}\text { FSC height } \\
\mathrm{H} \text { in m }\end{array}$ & $\begin{array}{c}\text { Rating } \\
\text { power } \mathrm{P}_{\mathrm{r}} \\
\text { in MW }\end{array}$ & $\begin{array}{c}\text { Construction } \\
\text { cost in million } \\
\text { EURO }\end{array}$ & $\begin{array}{c}\text { Construction } \\
\text { cost in EURO } \\
\text { per produced } \\
\text { KWh/year }\end{array}$ \\
\hline 0.25 & 36 & 720 & 1.0 & 2.75 & 0.64 \\
\hline 0.50 & 36 & 720 & 2.0 & 5.45 & 0.63 \\
\hline 0.75 & 36 & 720 & 3.0 & 7.35 & 0.57 \\
\hline 1.0 & 36 & 720 & 4.0 & 9.15 & 0.53 \\
\hline
\end{tabular}

Table 5. Direct construction cost of various SAEPs

\section{Floating Solar Chimney versus concrete chimney SAEPs}

The optimum dimensions and power ratings of the concrete solar chimney SAEPs are far higher than the Floating Solar Chimney dimensions and rating. In order for them to be compared we should consider a concrete solar chimney SAEP with given dimensions and construction cost and a Floating Solar Chimney SAEP farm generating annually the same electricity and having the same solar chimney height.

In a paper presented in 2005 (Shlaigh et al., 2005) it was mentioned the estimates on the construction cost of large SAEPs of concrete solar chimneys (Solar Updrafts Towers as they 
name them). According to these estimates concerning a $30 \mathrm{MW}$ SAEP with a concrete solar chimney of $750 \mathrm{~m}$ height and $70 \mathrm{~m}$ of internal diameter and a solar collector of $2900 \mathrm{~m}$ diameter( i.e. $6.6 \mathrm{Km}^{2}$ of surface area) the SAEP will generate 99 million $\mathrm{KWh}$ /year and will have a construction cost of 145 million EURO (2005 prices). Prof Jorg Schlaigh in a recent speech was estimating the construction cost of a similar concrete solar chimney SAEP of a solar chimney of $750 \mathrm{~m}$ height and $3 \mathrm{Km}$ diameter to be $250 \div 300$ million EURO (prices 2010).

Let us compare this concrete chimney SAEP with a farm of 9 Floating Solar Chimney SAEPs each one with a solar collector of surface area $740000 \mathrm{~m}^{2}$ (all of them together will cover approximately the same land area of the concrete solar chimney SAEP of $6.6 \mathrm{Km}^{2}$ ). Furthermore let as assume that all of them have the same FSC of $\sim 750 \mathrm{~m}$ height and an internal diameter of $\sim 40 \mathrm{~m}$. Let us also assume that the power rating of each FSC SAEP is $\sim 3 \mathrm{MW}$.

Although it is reasonable to assume that with these assumptions both electricity generating power plants will generate the same KWh of electricity per year ( $\sim 99$ million $\mathrm{KWh}$ /year), the FSC farm could generate $30 \%$ more electricity. This is the result of having a higher overall solar chimney cut in the farm of nine SAEPs, or equivalently the FSC farm will have an equivalent solar chimney diameter of $120 \mathrm{~m}(120 \mathrm{~m}=40 \mathrm{~m} \cdot \sqrt{9(S A E P S)})$. Thus the warm air speed, in the FSCs, is lower than the air speed within the concrete chimney, therefore the kinetic energy losses of the exit air are lower in the FSCs and the efficiency of the FSC farm is higher.

Using the previous construction cost relations the estimated construction cost of each Floating Solar Chimney SAEP of the farm is $\sim 6$ million EURO (2010 prices). Thus the whole FSC farm will have a construction cost of 54 million EURO.

The final result is that the capital expenditure for the Floating Solar Chimney farm, for similar electricity generation with the concrete solar chimney solar updraft tower, is 3 to 5 times smaller.

\section{Direct production cost of electricity KWh of the FSC technology}

\subsection{Direct production cost analysis}

The direct production cost of MWh of any electricity generating power plant is the sum of three costs:

- The capital cost related to the capital expenditure (CapEx) on investment

- The operation and maintenance cost

- The fuel cost

- The $\mathrm{CO}_{2}$ emission cost

For renewable technology PPs the fuel and the carbon dioxide emission costs are zero.

The base load continuous operating technologies are dominating the electricity generation and their average estimated direct production cost per MWh is, without any carbon

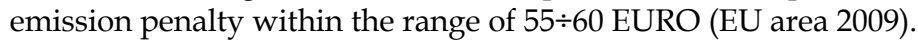

The onshore wind turbine farms have succeeded to generate electricity almost with the same cost in average. However it is generating intermittent electricity thus it can enter to the grid up to $45 \%$ in power and cover the $15 \div 20$ of the electricity demand.

Let us calculate the direct production cost of the solar chimney technology.

The assumptions we use are the following for FSC and concrete solar chimney SAEPs:

- The life cycle of both SAEPs is high (minimum 40 years) 
- The CapEx is a long term loan repaid in 40 equal installments

- The interest rate of above loans is $6 \%$ (2009)

- The fabric FSCs should be replaced every $6 \div 10$ years. This cost goes along with the maintenance cost.

- The initial construction period of the concrete chimney SAEPs is $3 \div 5$ years while the period for FSC SAEPs is $1 \div 2$ years. The repayments will start after those periods.

- Thus the annual repayment installment will be equal to $7 \%$ for the FSC farm and $7.5 \%$ for the concrete solar chimney PP (with the cost of initial grace period to be included)

- The rest operation and maintenance cost of both SAEPs is in the range of 5.0 EURO per generated MWh.

- The land lease is not included in the calculation because it is a negligible cost for desert or semi desert installation

In order to calculate the FSC technology average direct production cost we can use the figures of the previous paragraph for the SAEP farm of 9 similar units. The dimensions of which are $\mathrm{H}=750 \mathrm{~m}, \mathrm{~d}=40 \mathrm{~m}$ and $\mathrm{A}_{\mathrm{c}}=740000 \mathrm{~m}^{2}$. Each one of these SAEPs will have a rating power of $3 \mathrm{MW}$ and an annual generating ability of $\sim 12.9 \mathrm{GWh} /$ year. Thus their construction cost was estimated to 6 million. The Annual repayment amount for each FSC SAEP will be 420000 EURO or a capital cost of 32.3 EURO per produced MWh/year.

For the concrete SAEP we consider as a moderate estimation the amount of 200 million EURO construction cost with an annual generation of $\sim 100 \mathrm{GWh} /$ year. Thus the annual repayment cost will be 15 million EURO or a capital cost of $\sim 150 \mathrm{EURO}$ per MWh/year.

The fabric structure of the FSC should be replaced every $6 \div 10$ years. Its replacement cost is estimated to be $50 \cdot \mathrm{H} \cdot \mathrm{d}=1.5$ million EURO (present value) or a maximum of 250000 EURO/year i.e. 19.2EURO MWh/year (for 6 year replacement period).

The rest operation and maintenance cost for both SAEPs is $\sim 5$ EURO per produced MWh. Thus the direct production cost of MWh/year by the two technologies is:

- $\quad$ FSC technology $~ 56.5$ EURO/MWh

- Concrete solar chimney technology 155 EURO/MWh

Both SAEP technologies operate 24 hours/day year round and they can replace the base load fossil fueled power plants (Coal, Natural Gas and Nuclear).

\subsection{Direct production cost comparison}

The following table (6) gives the comparison of the major electricity generating technologies. The figures for the rest technologies are average values of collected official data, released by EU authorities in various publications.

The conventional base load electricity generating technologies are the coal and the natural gas fueled technologies of combined cycle and the nuclear fission technology. The first two technologies are emitting greenhouse gases and should sooner or later be replaced by alternative zero emission technologies, while the third-one although it is of zero emission technology it is considered to be dangerous and health hazardous technology. A necessary condition for the replacement of the base load electricity generating technologies by alternative renewable technologies is that these alternative technologies should operate continuously and their sources should be unlimited. The nuclear fusion technology is an alternative but its progress is slow, while the global warming threat demands urgent actions. That goes too for the promising carbon capture and storage technology, besides the problems related to carbon dioxide safe sequestration 


\begin{tabular}{|c|c|c|c|}
\hline $\begin{array}{l}\text { Fuel or Method of } \\
\text { Electricity Generation }\end{array}$ & $\begin{array}{l}\text { MWh Direct } \\
\text { Production Cost } \\
\text { in EURO }\end{array}$ & $\begin{array}{c}\text { Investment in EURO } \\
\text { per produced } \\
\text { MWh/year }\end{array}$ & $\begin{array}{l}\text { Mode of operation } \\
\text { and Capacity factor }\end{array}$ \\
\hline $\begin{array}{l}\text { Coal fired (not } \\
\text { including carbon } \\
\text { emission penalties) }\end{array}$ & $55-60$ & 200 & $\begin{array}{c}\text { Combined cycle base } \\
\text { load } 85 \%\end{array}$ \\
\hline $\begin{array}{c}\text { Coal fired with CCS } \\
\text { (Carbon capture and } \\
\text { storage) }\end{array}$ & $80-100$ & $300-400$ & $\begin{array}{c}\text { Combined cycle base } \\
\text { load } 85 \%\end{array}$ \\
\hline $\begin{array}{c}\text { Natural Gas fired } \\
\text { (not including carbon } \\
\text { emission penalties) }\end{array}$ & $60-65$ & 150 & Combined cycle $85 \%$ \\
\hline Nuclear Fission & $65-75$ & $400 \div 450$ & Base load 95\% \\
\hline Wind parks onshore & 60 & 500 & Intermittent 30\% \\
\hline Wind parks offshore & 75 & 650 & Intermittent 30\% \\
\hline $\begin{array}{c}\text { Concentrating Solar } \\
\text { CSP }\end{array}$ & 180 & 2000 & $\begin{array}{c}\text { Continuous with } \\
\text { thermal storage } 30 \%\end{array}$ \\
\hline Photo Voltaic PV & 280 & 3000 & Intermittent $15-17 \%$ \\
\hline Solar Chimney concrete & 155 & $\sim 2000$ & Continuous $\sim 50 \%$ \\
\hline Floating Solar Chimney & $\sim 60$ & $\sim 500$ & Continuous $\sim 50 \%$ \\
\hline Biomass & $55-75$ & $500-\div 700$ & Continuous $85 \%$ \\
\hline Geothermal & $50-70$ & $500-\div 800$ & $\begin{array}{l}\text { Continuous 90\% } \\
\text { (limited resource) }\end{array}$ \\
\hline Hydroelectric & $50-60$ & $500 \div 800$ & $\begin{array}{l}\text { Continuous (load } \\
\text { following, limited } \\
\text { resource) }\end{array}$ \\
\hline
\end{tabular}

Table 6. A cost comparison of electricity generating technologies

The wind and solar technologies are appropriate technologies if they are equipped with massive energy storage systems for continuous operation. With today's technology only the solar concentrating power plants (CSP) can be equipped with cost effective thermal energy storage systems and generate continuous electricity. However their MWh direct production cost is three times higher in comparison with the respective cost of the existing base load technologies. The FSC technology is by nature equipped with ground thermal storage and operates continuously. Due to its low investment cost and its almost equal direct production cost to the conventional base load electricity technologies it is an ideal candidate to replace the fossil fueled base load technologies.

\section{Large scale application of the FSC technology in deserts}

\subsection{Desert solar technologies}

The mid-latitude desert or semi desert areas of our planet are more than enough in order to cover the present and any future demand for solar electricity. According to most conservative estimations, a $3 \%$ of these areas with only $1 \%$ efficiency for solar electricity generation can supply $50 \%$ of our future electricity demand. Also these kinds of lands exist in all continents and near the major carbon emitting countries (USA, China, EU and India). 
The desert solar technologies for continuous electricity generation are the following:

- The photo voltaic (PV) large scale farms equipped with batteries

- The concentrating solar power plants (CSP) equipped with thermal storage tanks

- The concrete solar chimney SAEPs or Solar Up-draft Towers

- $\quad$ The floating solar chimney (FSC) farms

The following table (7) is giving us a comprehensive comparison of these desert solar technologies (OM means operation and maintenance).

\begin{tabular}{|c|c|c|c|c|}
\hline $\begin{array}{c}\text { Desert } \\
\text { Technology of } \\
\text { continuous } \\
\text { operation }\end{array}$ & Major benefits & Major problems & $\begin{array}{l}\text { MWh Direct } \\
\text { production cost } \\
\text { in EURO }\end{array}$ & $\begin{array}{l}\text { Investment per } \\
\text { produced } \\
\text { MWh/year }\end{array}$ \\
\hline $\begin{array}{c}\text { PV with } \\
\text { energy storage } \\
\text { batteries }\end{array}$ & $\begin{array}{l}\text {-Demands no } \\
\text { water } \\
\text {-Low OM care } \\
\text { and cost }\end{array}$ & $\begin{array}{c}\text {-The replacement } \\
\text { cost of the } \\
\text { batteries }\end{array}$ & $\begin{array}{l}\text { Very high } \\
280\end{array}$ & $\begin{array}{l}\text { Very high } \\
>3000\end{array}$ \\
\hline $\begin{array}{l}\text { CSP with } \\
\text { thermal } \\
\text { storage }\end{array}$ & $\begin{array}{l}\text {-Low cost } \\
\text { thermal storage }\end{array}$ & $\begin{array}{l}\text {-Demands water } \\
\text { for its operation } \\
\text {-Demands OM } \\
\text { personnel on site }\end{array}$ & $\begin{array}{l}\text { High } \\
180\end{array}$ & $\begin{array}{l}\text { High } \\
>2000\end{array}$ \\
\hline $\begin{array}{l}\text { Solar up-draft } \\
\text { Tower } \\
\text { (concrete solar } \\
\text { chimney) }\end{array}$ & $\begin{array}{c}\text { - No water } \\
\text { demand } \\
\text {-High operating } \\
\text { life } \\
\text {-Low OM care } \\
\text { and cost }\end{array}$ & $\begin{array}{c}\text {-High initial cost } \\
\text {-High } \\
\text { construction } \\
\text { period on site }\end{array}$ & $\begin{array}{l}\text { High } \\
155\end{array}$ & $\begin{array}{l}\text { High } \\
>2000\end{array}$ \\
\hline $\begin{array}{l}\text { Floating Solar } \\
\text { Chimney }\end{array}$ & $\begin{array}{c}\text {-No water } \\
\text { demand } \\
\text {-Easy and fast } \\
\text { deployment on } \\
\text { site } \\
\text {-Low OM care }\end{array}$ & $\begin{array}{c}\text {-Periodic } \\
\text { replacement of } \\
\text { the FSC fabric } \\
\text { parts }\end{array}$ & $\begin{array}{l}\text { Low } \\
60\end{array}$ & $\begin{array}{l}\text { Low } \\
500\end{array}$ \\
\hline
\end{tabular}

Table 7. Comparison of desert solar technologies

\subsection{The Desertec project}

The Desertec project is a proposal to EU for using the desert or semi desert areas in MENA area (Middle East and North Africa) in order to generate solar electricity. Using an appropriate area of $300 \mathrm{KmX} 300 \mathrm{Km}$ in MENA with only $1 \%$ efficiency up to $50 \%$ of its present and future electricity demand can be generated.

The transmission of the generated electricity to the EU can be achieved by using UHVDC (Ultra High Voltage Direct Curent) lines. Using the existing technology up to $6.4 \mathrm{GW}$ of electricity power can be transmitted by only one UHVDC line of two conductors $( \pm 800 \mathrm{KV}$ and 4000A).

The UHVDC lines can be overhead, underground or undersea lines with different construction costs but the same safety and reliability. 
The farm of desert power plants generates AC electricity (up to 6.4 GW). This AC electricity is converted to DC electricity, at a special power station near the farm. Through a UHVDC line the DC electricity is transmitted to the chosen place of EU, where a reverse converter power station is transforming the DC to AC electricity with the suitable characteristics for the EU local grid.

The losses of the UHVDC transmission (including the losses of two converting power stations) are not more than $\sim 5 \%$ per $2000 \mathrm{Km}$ of transmission distance. Their construction cost for $2000 \mathrm{Km}$ average distance between MENA and EU areas, depends on the mode of the UHVDC line and will range between $1 \div 2$ Billion EURO.

The following table shows a comparison cost for an electricity generation system of $6.4 \mathrm{GW}$ installed in MENA area and transmitting its electricity power to a EU grid for a distance of $2000 \mathrm{Km}$. It is assumed that due to the energy storage systems of all the desert power plants their capacity factor is more or less similar $(\sim 50 \%)$. This practically means that the desert solar farms would generate electricity of $\sim 6.4 \mathrm{GW} \times(8760 / 2)$ hours $\approx 28000 \mathrm{GWh} /$ year, of which $\sim 95 \%$ or $\sim 26500 \mathrm{GWh} /$ year (or $26.5 \mathrm{TWh} /$ year) will be transmitted to the EU chosen place.

In order to cover $40 \div 50 \%$ of the present and future EU electricity demand i.e. $1060 \div 1500$ TWh/year we should build a set of 40 to 56 independent solar farms of $6.4 \mathrm{GW}$ that can be installed in appropriate MENA areas and connected through UHVDC lines to the proper places of EU countries. In order to build 40-56 farms we should invest capital of the amounts as shown in the next table (8) for respective technologies.

\begin{tabular}{|c|c|c|c|}
\hline $\begin{array}{c}\text { Desert Technology } \\
\text { of continuous } \\
\text { operation }\end{array}$ & $\begin{array}{l}\text { Investment cost } \\
\text { (including UHVDC lines } \\
\text { cost of } 1.5 \text { billion EURO) } \\
\text { for the solar farm of } \\
6.4 \mathrm{GW} \text { in billion EURO }\end{array}$ & $\begin{array}{l}\text { Investment cost for } \\
\text { building } 40 \div 56 \\
\text { similar solar farms } \\
\text { in billion EURO }\end{array}$ & $\begin{array}{l}\text { MWh direct } \\
\text { production cost in } \\
\text { EURO }(26.5 \mathrm{TWh} \\
\text { supplied to EU })\end{array}$ \\
\hline $\begin{array}{l}\text { PV with energy } \\
\text { storage batteries }\end{array}$ & $>85.5$ & $\begin{array}{l}3420 \\
4778\end{array}$ & $>285$ \\
\hline $\begin{array}{l}\text { CSP (parabolic } \\
\text { through or tower) } \\
\text { with thermal } \\
\text { storage }\end{array}$ & 57.5 & $\begin{array}{l}2300 \\
3220\end{array}$ & 185 \\
\hline $\begin{array}{l}\text { Solar up-draft } \\
\text { Towers }\end{array}$ & 57.5 & $\begin{array}{l}2300 \\
3220\end{array}$ & 160 \\
\hline $\begin{array}{l}\text { Floating Solar } \\
\text { Chimney }\end{array}$ & 15.5 & $\begin{array}{l}620 \\
868\end{array}$ & 65 \\
\hline
\end{tabular}

Table 8. Cost comparison of solar desert farms of 6.4 GW

The maximum desert or semi desert area for the installation of one solar farm of $6.4 \mathrm{GW}$ is not more than $1600 \mathrm{Km}^{2}$ or a square area $\sim(40 \mathrm{Km} \mathrm{X} 40 \mathrm{Km})$. Thus the maximum neaded area in order to cover the $40 \div 50 \%$ of the present and future EU electricity demand, with zero emission solar electricity, is $64000 \div 90000 \mathrm{Km}^{2}$ (i.e. a square area of $250 \mathrm{Km} \mathrm{X} 250 \mathrm{Km}$ up to $300 \mathrm{Km} \times 300 \mathrm{Km}$ ) 
This maximum area is indispensable for solar chimney farms (concrete or floating) of $1 \%$ efficiency. As for the rest solar technologies a much smaller desert area is adequate. However the maximum area needed is not more than $2 \%$ of proper desert or semi desert area in MENA territory.

By the presented data it is evident that the FSC technology has tremendous benefits in comparison with its solar competitors for desert application.

Its major benefits are:

- Low investment cost

- Low KWh direct production cost (almost the same with the fuel consuming base load electricity generating technologies)

- 24hours/day uninterrupted operation due to the ground thermal storage

- The daily power profile can be as smooth as necessary using low cost additional thermal storage

- Demands no water for its operation and maintenance

- Easy and fast deployment on site

- It uses recycling and low energy production materials (mainly plastic and glass)

- Minimum personnel on site during its construction and operation

Large scale desert application of the Floating Solar Chimney technology can be one of the major tools for global warming elimination and sustainable development.

\section{Climate change warning}

Climate change indications due to the global warming threat are accelerating. Climate change policies should be agreed upon and urgent measures should be taken. Global warming due to greenhouse gases emissions $\left(\mathrm{CO}_{2}, \mathrm{CH}_{4}\right.$ etc.) is a reality scientifically documented.

Intergovernmental Panel on Climate Change (IPCC) is a Nobel Priced UN committee studying carefully and objectively the global warming due to greenhouse gases produced by human activity on earth. The major producer is the fossil fuels used in residential, industrial, and transportation activities, of which the major-one is the electricity generation of fossil fueled power plants. According to IPCC estimations the global average temperature increase on earth will follow the pattern shown in the next figure (19) depending on our future model of energy use, electricity generation scenarios and greenhouse gases concentration. According to mentioned estimations, pertaining the existing technology and applying an internationally agreed upon strict policy on greenhouse gas emissions, the scenario most likely to come up is an eventuality between I and II.

According to mentioned scientifically documented estimations, global temperatures in excess of 1.9 to $4.6^{\circ} \mathrm{C}$ warmer than pre-industrial would appear and it will be possibly sustained for centuries.

The major global warming effects on our planet, according to IPCC are:

- Anthropogenic warming and sea level rise would continue for centuries even if the greenhouse gas concentrations were to be stabilized

- Eventual melting of the Greenland ice sheet, would raise the sea level by $7 \mathrm{~m}$ compared to 125,000 years ago

- Due to precipitation changes fertile land devastation is possible to appear in many areas

- The existing atmospheric models can not exclude the appearance of extreme catastrophic atmospheric phenomena such as: very strong typhoons, tornados, snow or hail storms etc. 


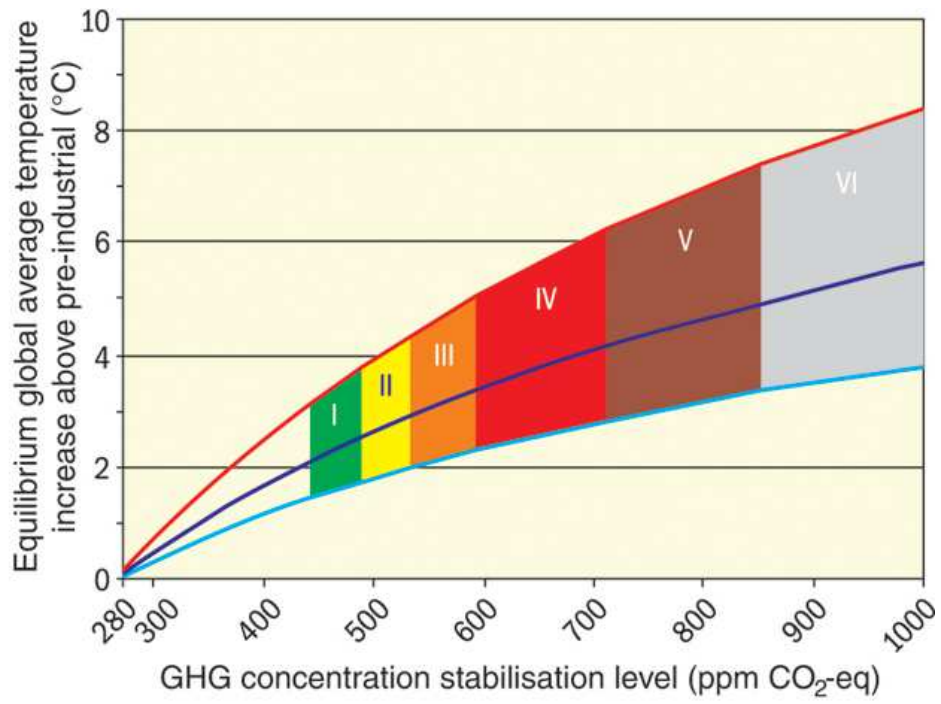

Fig. 19. IPCC scenarios of global temperature increase

The energy sector is the major source of the greenhouse gases due to its fossil fuelled technologies of electricity generation, transportation, industrial activities etc. For the year of 2010 an estimated quantity of 29,000 Mt of carbon dioxide will be spread all over the environment from fossil fuel combustion of which:

- $36.4 \%$ from electricity generation

- $20.8 \%$ from the industry

- $18.8 \%$ from transport and

- $14.2 \%$ from household, service and agriculture and

- $9.8 \%$ from international bunkers

The mechanism of Kyoto protocol aims to create an "objective" over the external cost at least for the threatening carbon dioxide $\left(\mathrm{CO}_{2}\right)$ emissions through trading their rights.

The cost of the emitted $\mathrm{CO}_{2}$, sooner or later it will reach at prices 20-30 EURO per ton of $\mathrm{CO}_{2}$ and after the year 2012 for EU the fossil fuelled PPs should pay for each ton of $\mathrm{CO}_{2}$ emitted by them. Taking into consideration that $1 \mathrm{Kg}$ of coal has a thermal energy of $\sim 8.14 \mathrm{KWh}$, thus a modern coal fired power plant with efficiency $\sim 45 \%$ will generate by this $\sim 3.66 \mathrm{KWh}$ and will emit to the environment $3.667 \mathrm{Kg}$ of $\mathrm{CO}_{2}$. Thus in a modern coal fired plant approximately $1.0 \mathrm{Kg}$ of $\mathrm{CO}_{2}$ is emitted per generated $\mathrm{KWh}$. For the lignite coal fired power plants this figure is $50 \%$ higher and for modern combined cycle natural gas power plants could be $50 \%$ smaller.

\section{Conclusion}

Although electricity generation is a major carbon dioxide producer we should notice that electricity can replace all the energy activities related to fossil fuelled technologies. Thus a solution to the global warming is possible if we succeed to generate zero emission clean electricity. 
The renewable electricity generating technologies is a major tool, some believe that it should be the exclusive technology, towards the aim of eliminating the greenhouse emissions threatening the future on our planet.

It is possible to mitigate global warming if the world-wide consumption of fossil fuels can be drastically reduced within the next 10 to 15 years. I believe that the only viable scenario that could lead to a successful and real reduction of fossil fuels is the large scale application of the FSC technology in desert or semi desert areas. This means that we should start building, for the next 30 years, Floating Solar Chimney SAEP desert farms of overall rating power $\sim 160 \mathrm{GW} /$ year, that could generate $\sim 720 \mathrm{TWh} /$ year.

Thus for the next 30 years we will build SAEP desert farms generating more than 21600 TWh/year solar electricity that could replace fossil fuelled generated electricity. The global investment cost for this choice will not exceed the amount of 360 billion EURO/year or 11.5 trillion EURO for the next 30 years. These investments in electricity generation are reasonable taking into consideration that the future electricity demand could reach the $45000 \mathrm{TWh}$. The necessary land for the 30 years FSC power plants is $1.000 .000 \mathrm{Km}^{2}(1000 \mathrm{Km}$ $\mathrm{X} 1000 \mathrm{Km})$

\section{References}

[1] Bernades M.A. dos S., Vob A., Weinrebe G., 2003 “Thermal and technical analyses of solar chimneys" Solar Energy 75 ELSEVIER, pp. 511-52.

[2] Backstrom T, Gannon A. 2000, "Compressible Flow Through Solar Power Plant Chimneys". August vol 122/ pp.138-145.

[3] Gannon A. , Von Backstrom T 2000, "Solar Chimney Cycle Analysis with System loss and solar Collector Performance", Journal of Solar Energy Engineering, August Vol 122/pp.133-137.

[4] Papageorgiou C. 2004 "Solar Turbine Power Stations with Floating Solar Chimneys". IASTED proceedings of Power and Energy Systems, EuroPES 2004. Rhodes Greece, july 2004 pp,151-158

[5] Papageorgiou C. 2004, "External Wind Effects on Floating Solar Chimney" IASTED Proceedings of Power and Energy Systems, EuroPES 2004, Conference, Rhodes Greece ,July 20042004 pp.159-163

[6] Papageorgiou C. 2004, "Efficiency of solar air turbine power stations with floating solar chimneys" IASTED Proceedings of Power and Energy Systems Conference Florida, November 2004, pp. 127-134.

[7] Papageorgiou C. "Floating Solar Chimney" E.U. Patent 1618302 April. 29, 2009.

[8] Pretorius J.P., Kroger D.G. 2006, "Solar Chimney Power Plant Performance“, Journal of Solar Energy Engineering, August 2006, Vol 128 pp.302-311

[9] Pretorius J., "Optimization and Control of a Large-scale Solar Chimney Power Plant" Ph.D. dissertation, Dept. Mechanical Eng., Univ. Stellenbosch 7602 Matieland, South Africa 2007.

[10] Schlaich J. 1995, "The Solar Chimney: Electricity from the sun" Axel Mengers Edition, Stutgart

[11] J. Schlaich J. e.al 2005, "Design of commercial Solar Updraft Tower Systems-Utilization of Solar Induced Convective Flows for Power Generation" Journal of Solar Energy Engineering Feb. 2005 vol 127, pp. 117-124R.

[12] White F. "Fluid Mechanics" 4th Edition McGraw-Hill N.York 1999 


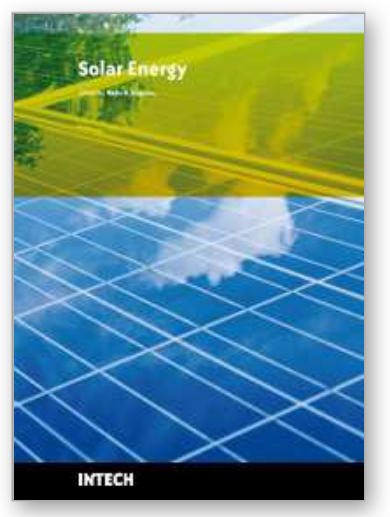

\author{
Solar Energy \\ Edited by Radu D Rugescu
}

ISBN 978-953-307-052-0

Hard cover, 432 pages

Publisher InTech

Published online 01, February, 2010

Published in print edition February, 2010

The present "Solar Energy" science book hopefully opens a series of other first-hand texts in new technologies with practical impact and subsequent interest. They might include the ecological combustion of fossil fuels, space technology in the benefit of local and remote communities, new trends in the development of secure Internet Communications on an interplanetary scale, new breakthroughs in the propulsion technology and others. The editors will be pleased to see that the present book is open to debate and they will wait for the readers' reaction with great interest. Critics and proposals will be equally welcomed.

\title{
How to reference
}

In order to correctly reference this scholarly work, feel free to copy and paste the following:

Christos D. Papageorgiou (2010). Floating Solar Chimney Technology, Solar Energy, Radu D Rugescu (Ed.), ISBN: 978-953-307-052-0, InTech, Available from: http://www.intechopen.com/books/solar-energy/floatingsolar-chimney-technology

\section{INTECH}

open science | open minds

\author{
InTech Europe \\ University Campus STeP Ri \\ Slavka Krautzeka 83/A \\ 51000 Rijeka, Croatia \\ Phone: +385 (51) 770447 \\ Fax: +385 (51) 686166 \\ www.intechopen.com
}

\author{
InTech China \\ Unit 405, Office Block, Hotel Equatorial Shanghai \\ No.65, Yan An Road (West), Shanghai, 200040, China \\ 中国上海市延安西路65号上海国际贵都大饭店办公楼405单元 \\ Phone: +86-21-62489820 \\ Fax: +86-21-62489821
}


(C) 2010 The Author(s). Licensee IntechOpen. This chapter is distributed under the terms of the Creative Commons Attribution-NonCommercialShareAlike-3.0 License, which permits use, distribution and reproduction for non-commercial purposes, provided the original is properly cited and derivative works building on this content are distributed under the same license. 